\title{
Enhanced Biomechanical Properties of Polyvinyl Alcohol-Based Hybrid Scaffolds for Cartilage Tissue Engineering
}

\author{
Silvia Barbon ${ }^{1,2}{ }^{\oplus}$, Martina Contran ${ }^{1}$, Elena Stocco ${ }^{1,2}$, Silvia Todros $^{3}{ }^{(\mathbb{C}}$, Veronica Macchi ${ }^{1,2}{ }^{(D)}$, \\ Raffaele De Caro ${ }^{1,2}$ (D) and Andrea Porzionato 1,2,* \\ 1 Department of Neuroscience, Section of Human Anatomy, University of Padova, Via A. Gabelli 65, \\ 35121 Padova, Italy; silvia.barbon@unipd.it (S.B.); martina.contran@unipd.it (M.C.); \\ elena.stocco@gmail.com (E.S.); veronica.macchi@unipd.it (V.M.); raffaele.decaro@unipd.it (R.D.C.) \\ 2 L.i.f.e.L.a.b. Program, Consorzio per la Ricerca Sanitaria (CORIS), Veneto Region, Via N. Giustiniani 2, \\ 35128 Padova, Italy \\ 3 Department of Industrial Engineering, Centre for Mechanics of Biological Materials, University of Padova, \\ Via Venezia 1, 35131 Padova, Italy; silvia.todros@unipd.it \\ * Correspondence: andrea.porzionato@unipd.it; Tel.: +39-049-827-2314
}

Citation: Barbon, S.; Contran, M.; Stocco, E.; Todros, S.; Macchi, V.; Caro, R.D.; Porzionato, A. Enhanced Biomechanical Properties of Polyvinyl Alcohol-Based Hybrid Scaffolds for Cartilage Tissue Engineering. Processes 2021, 9, 730. https://doi.org/10.3390/pr9050730

Academic Editor: Selestina Gorgieva

Received: 8 March 2021

Accepted: 19 April 2021

Published: 21 April 2021

Publisher's Note: MDPI stays neutral with regard to jurisdictional claims in published maps and institutional affiliations.

Copyright: (c) 2021 by the authors. Licensee MDPI, Basel, Switzerland This article is an open access article distributed under the terms and conditions of the Creative Commons Attribution (CC BY) license (https:// creativecommons.org/licenses/by/ $4.0 /)$.

\begin{abstract}
Articular cartilage damage is a primary feature of osteoarthritis and other inflammatory joint diseases (i.e., rheumatoid arthritis). Repairing articular cartilage is highly challenging due to its avascular/aneural nature and low cellularity. To induce functional neocartilage formation, the tissue substitute must have mechanical properties which can adapt well to the loading conditions of the joint. Among the various biomaterials which may function as cartilage replacements, polyvinyl alcohol (PVA) hydrogels stand out for their high biocompatibility and tunable mechanical features. This review article describes and discusses the enrichment of PVA with natural materials (i.e., collagen, hyaluronic acid, hydroxyapatite, chitosan, alginate, extracellular matrix) \pm synthetic additives (i.e., polyacrylic acid, poly-lactic-co-glycolic acid, poly(ethylene glycol) diacrylate, graphene oxide, bioactive glass) to produce cartilage substitutes with enhanced mechanical performance. PVA-based hybrid scaffolds have been investigated mainly by compression, tensile, friction, stress relaxation and creep tests, demonstrating increased stiffness and friction properties, and with cartilage-like viscoelastic behavior. In vitro and in vivo biocompatibility studies revealed positive outcomes but also many gaps yet to be addressed. Thus, recommendations for future research are proposed in order to prompt further progress in the fabrication of PVA-based hybrid scaffolds which increasingly match the biological and mechanical properties of native cartilage.
\end{abstract}

Keywords: polyvinyl alcohol; natural materials; hybrid scaffold; mechanical properties; cartilage regeneration; osteoarthritis

\section{Introduction}

Articular cartilage $(\mathrm{AC})$ is made up of native extracellular matrix which possesses distinct biochemical, biomechanical, and structural properties and is dynamically regulated by chondrocytes. Thanks to its highly specialized structure and composition, AC is known to provide mechanical stability and load bearing capacity [1-3]. Being mainly a result of traumatic events or degenerative and inflammatory joint diseases such as osteoarthritis (OA) and rheumatoid arthritis (RA), cartilage lesions represent a widespread health problem, causing pain and disability for patients [4,5]. According to the World Health Organization, OA represents the most common type of degenerative arthritis, affecting about $9.6 \%$ of men and $18 \%$ of women aged over 60 years worldwide, with $25 \%$ of patients having disabilities [6,7]. OA develops through a series of pathological changes caused by injury, aging, inflammation events, or genetic factors, and leading to AC degeneration [6]. The clinical management of cartilage damage/degeneration remains a challenging issue for modern orthopedic medicine since the lack of vascularity in the tissue leads to low 
regenerative and self-healing capabilities. Current treatment options include total joint arthroplasty, marrow stimulating techniques, mosaicplasty, microfracture, multiple drilling, and autogenous/allogeneic chondrocyte transplantation [8-10]. However, these repair approaches still suffer from variable outcomes and important limitations which prevent satisfactory functional recovery (i.e., donor site morbidity, formation of fibrocartilage rather than hyaline cartilage, and poor integration with the host tissue) [11]. Thus, tissue engineering (TE) strategies based on the use of stem cells, soluble factors, and scaffolds are taken into growing consideration to fill the gap [12-16]. The application of stem cells and soluble factors is well documented in the correction of cartilage defects, but recent evidence suggests that cartilage tissue homeostasis and regeneration could be restored by mimicking the physicochemical and mechanical cues with the use of biomimetic scaffolds $[17,18]$. Various scaffold biomaterials have been tested so far for cartilage TE purposes, including both natural (i.e., collagen, hyaluronic acid, chitosan, silk fibroin, gelatin) and synthetic (polycaprolactone, polylactic-co-glycolic acid, poly(L-lactic acid), polyurethane) polymers, or a combination of the two (reviewed, for example, by Bhardwaj et al. [11] and Gaut and Sugaya [19]). Among polymeric scaffolds intended for cartilage TE, three-dimensional (3D) supports based on mechanically robust hydrogels are also under investigation, taking advantage of their peculiar properties in terms of porosity, pore size, and matrix rigidity $[20,21]$. Being widely employed in the biomedical field due its biocompatibility and nontoxicity, polyvinyl alcohol (PVA) hydrogel shows proper moisture content and tunable mechanical properties which render it a promising candidate for the development of synthetic cartilage [22-25]. Interestingly, biomimetic properties of PVA hydrogels can be improved by the combination with natural materials, showing higher propensity for cell-to-matrix and cell-to-cell interaction (i.e., hyaluronic acid, chitosan, cartilage acellular matrix) such that the 3D system can better mimic the in vivo functions and tissue architecture [26]. Besides ameliorating biological performances of PVA, the fabrication of these composite scaffolds also focuses on giving the engineered construct mechanical properties that perfectly resemble the characteristics of the native cartilaginous tissue.

This review describes the mechanical tests performed on PVA-based hybrid scaffolds specifically designed for cartilage TE, aiming at highlighting their enhanced biomechanical properties as cartilage substitutes. After presenting the peculiar structure and biomechanics of AC, PVA hydrogels are introduced as promising biomaterials which are already in use in the orthopedic clinical practice due to their mechanical features well resembling native AC. After that, the main focus of the review is on the design of PVA-based biohybrid scaffolds and the investigation of their biomechanical/biocompatibility properties which may encourage their use in cartilage TE.

\section{Materials and Methods}

PRISMA guidelines were applied to the literature search of this review [27] (Figure 1). PubMed and SCOPUS databases were searched for full text original articles in English using the keywords "polyvinyl alcohol", "PVA", "hybrid scaffold", "cartilage regeneration" in different combinations. The inclusion criteria for paper eligibility regarded (a) the fabrication of PVA-based scaffolds, (b) the combination of PVA with natural or natural + synthetic materials to obtain hybrid constructs, (c) the realization of mechanical tests on the composites, and (d) cartilage tissue regeneration as the end use destination of the scaffolds. The reference lists of the identified articles were also taken into consideration for enriching the review. A total of 31 papers were included in the review. 

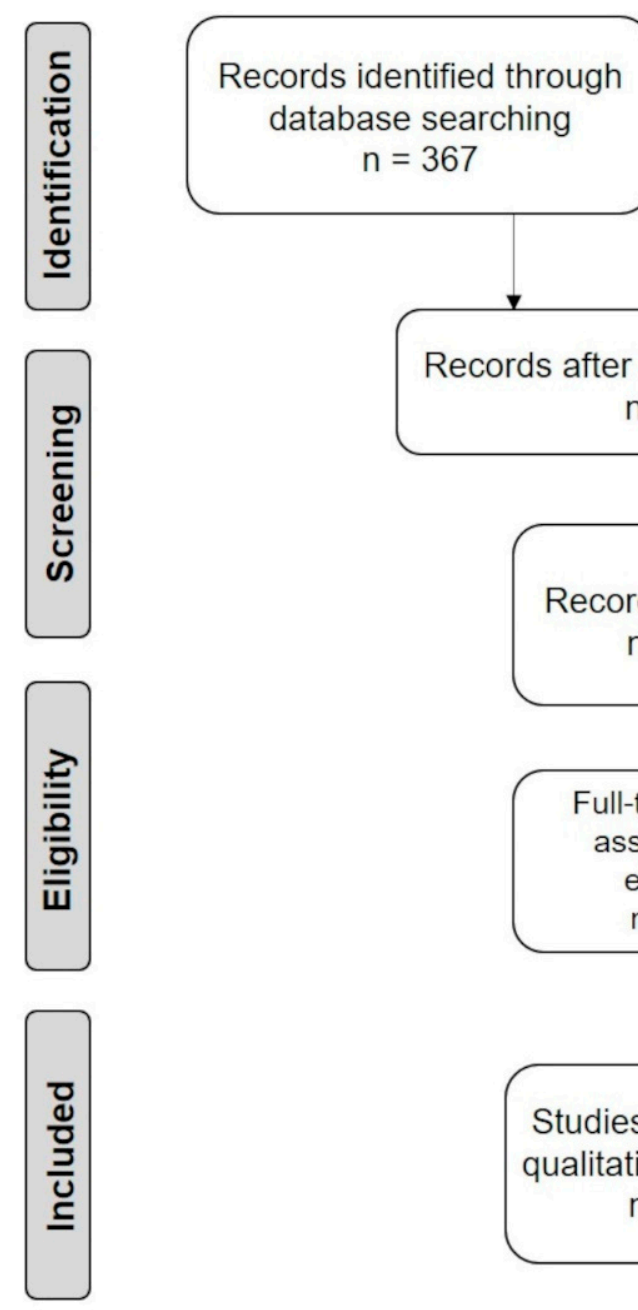

\section{Additional records identified} through other sources $\mathrm{n}=135$

Figure 1. Flow diagram representing the literature search.

\section{Biomechanical Implications in Cartilage Regeneration}

\subsection{The Peculiar Structure of Articular Cartilage}

Articular cartilage is considered to be the typical hyaline cartilage exhibiting highly specialized structure and composition, which provides unique mechanical and tribological properties to withstand the demands of repetitive joint loading [28]. This viscoelastic connective tissue constitutes an interface between bones to minimize friction, bear, and transfer load and allow for translation and rotation [3]. It is mainly formed by water and extracellular matrix (ECM) components (i.e., collagen, proteoglycans, hyaluronic acid), which confer high strength and elasticity. In particular, type II collagen accounts for $90-95 \%$ of the collagen fraction in $\mathrm{AC}$, assuring for the shear resistance of the tissue. On the other hand, proteoglycan and hyaluronic acid crosslink to form a network that entraps a large amount of water and are responsible for the elasticity and compressive resistance of the tissue [18]. Chondrocytes are the single-type cell population which is responsible for the production of cartilage ECM (Figure 2). Regarding its peculiar structure, cartilage tissue is typically divided into four regions: superficial zone, transitional or middle zone, deep zone, and calcified cartilage zone. Within each zone, chondrocytes exhibit different shape, size, and orientation, with metabolic activity and response to mechanical loading which vary according to the considered region [19]. The proteoglycan content progressively increases from the superficial to the deep zone. The resulting collagen fibers are (i) aligned parallel with the joint surface in the superficial zone, (ii) unaligned and tangential to the cartilage surface in the middle zone, (iii) radially arranged in the deep zone, and (iv) little organized and mineralized in the calcified zone close to the bone $[19,29]$. This hierarchical structure 
is well-adapted to the mechanical environment of articular cartilage, with the superficial layer being mainly functional to withstand the shear load, and the middle/deep zones being more suitable to bear the compression load [30].
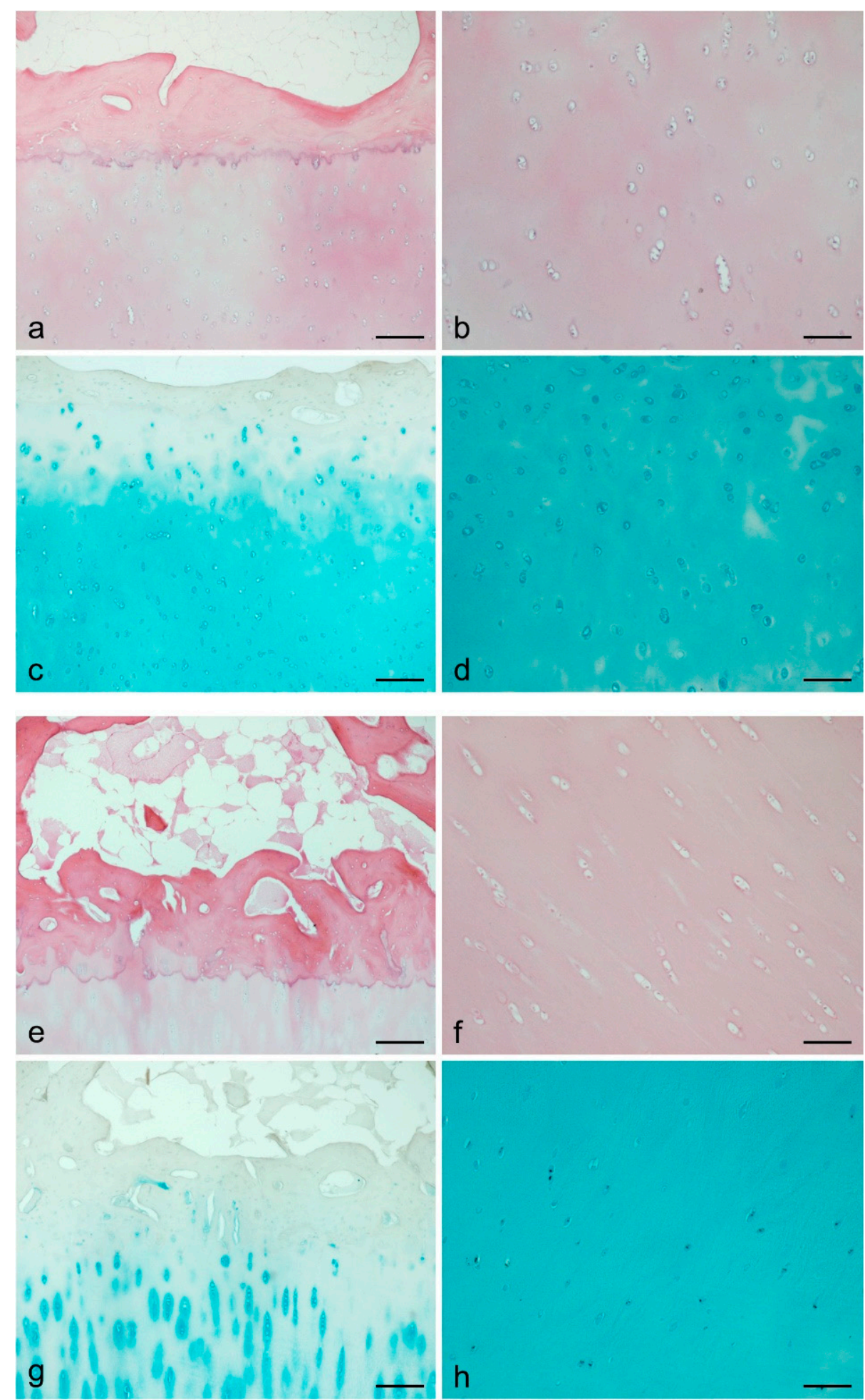

Figure 2. Histological morphology of humeral (a-d) and patellar (e-h) articular cartilage after hematoxylin and eosin $(\mathbf{a}, \mathbf{b}, \mathbf{e}, \mathbf{f})$ staining. In parallel, acidic polysaccharides (i.e., glycosaminoglycans) were stained by Alcian blue (c,d,g,h) in both samples. Scale bar: $(\mathbf{a}, \mathbf{c}, \mathbf{e}, \mathbf{g}) 200 \mu \mathrm{m} ;(\mathbf{b}, \mathbf{d}, \mathbf{f}, \mathbf{h}) 100 \mu \mathrm{m}$. 


\subsection{Tissue Biomechanics}

In physiological conditions, cartilage tissue shows little or no wear, even after millions of loading cycles, and may withstand loads up to 10 times higher than body weight. This unique property is ascribable to the complex structure and composition of cartilage ECM, which makes it a water-trapping, fibrous, and multiphasic material with anisotropic, nonlinear, inhomogeneous, and viscoelastic mechanical behavior [31]. Remarkably, the biphasic and viscoelastic nature of cartilage directly affects its compressive, tensile and shear responses since loads are heterogeneously distributed along the different tissue zones [3].

Articular cartilage can bear substantial loads thank to the combination of frictional resistance to water flow and water pressurization within the ECM. Under constant loading, the synovial liquid is pressurized and flows through the tissue, exerting friction resistance on the solid matrix and thus transferring the load [3].

Compressive properties of cartilaginous tissue are the result of the combination of its permeability and viscoelasticity. Due to low permeability $\left(10^{-16}-10^{-15} \mathrm{~m}^{4} \mathrm{~N}^{-1} \mathrm{~s}^{-1}\right)$, fast pressurization of the interstitial fluid occurs. Upon compressive loading, the entrapped fluid starts to flow, but it hardly permeates the material, being pressurized and giving rise to friction resistance forces which dissipate the stress [32].

Aggrecan, the main proteoglycan in AC, is the main component responsible for tissue osmotic properties, which determine its ability to oppose compressive loads. When AC is subjected to compression, the negatively charged sites on the aggregated proteoglycans are pressed together such that they repel each other with higher intensity and contribute to the compressive stiffness of the tissue [19].

Under compressive forces, AC undergoes deformation and tensile stress is generated tangentially to its surface. If this force is persistent over time, it elicits a viscoelastic response caused by the movement of the collagen fibers. At the beginning of the loading stage, small stresses translate into large strains, due to the permeability of the superficial zone. Subsequently, the sliding of collagen fibers through proteoglycans requires higher stress to induce the same level of strain until the final stage, when collagen fibers stretch to withstand the applied stress, producing a linear elastic response up to $15 \%$ strain [33]. The mechanical response of cartilage is mainly governed by the collagen and proteoglycan components (solid phase). As the orientation, concentration, and density of collagen fibers change along the depth of the tissue, the tensile stress-strain profile results strongly depend on AC zones. A Young's modulus ranging between 5 and $25 \mathrm{MPa}$ has been measured depending on tissue zones, with higher values in the superficial zone rather than in the middle/deep zones [3].

Translational/rotational movements of bones produce shear stresses on AC, which are also supported by the solid phase of the tissue. The equilibrium shear modulus has been measured to be $0.05-0.25 \mathrm{MPa}$. The dynamic shear modulus and the loss angle have been calculated as $0.1-4 \mathrm{MPa}$ and $\sim 10^{\circ}$, respectively [3].

These complex tissue mechanics make the engineered repair of AC particularly challenging from a biomechanical point of view.

\subsection{PVA-Based Scaffolds for the Mechanical Support in Cartilage Healing}

The key mechanical features required for $\mathrm{AC}$ regeneration are high creep resistance to promote the mechanical stability of the joint and high water content to maintain a lubricious surface and minimize cartilage damage during articulation [34]. A certain bioactivity is also required to sustain cell attachment/migration, and the scaffold material should retain biodegradation capacity and the possibility to remodel as the new cartilage forms and replaces the implanted construct. From this perspective, hydrogel materials are known to accomplish most of these features, and so they have found use in numerous cartilage biomedical applications [35]. Among them, PVA has gained more and more attention among researchers in artificial cartilage replacements due to its virtues of high biocompatibility, rubber elastic physical properties, and low friction coefficient and capacity 
to enable biphasic lubrication instead of boundary lubrication [36]. In addition, this hydrogel offers the great possibility to be specifically fabricated with tensile strength in the cartilage range (i.e., 1-17 MPa) [37]. For these reasons, PVA is used in orthopedic surgery as a prosthesis for the treatment of focal articular lesions. Cartiva ${ }^{\circledR}$ biomaterials (Carticept Medical) are examples of PVA devices that have been designed to behave like natural cartilage [37] and a PVA-based hydrogel named Salubria ${ }^{\mathrm{TM}}$ (Salumedic) is marketed in Europe and Canada for the clinical treatment of AC damage [38].

In the effort to ameliorate their performance as AC substitutes, different concentrations of PVA-based hydrogels are currently under investigation for their application in the orthopedic field. Weller [39] recently reported the use of 40\% PVA hydrogel supports for treating thumb carpometacarpal arthroplasty, demonstrating that the tensile strength, compressive modulus, and coefficient of friction of the material highly resembled the mechanical properties of the native cartilage. Hendriks and collaborators [40] investigated a scaffold composed by macroporous and not biodegradable PVA hydrogel for the reparation of focal cartilage lesions. The scaffold was conceived for possessing a porous structure that contributes to the integration with host tissue through the migration of the cells on the support and the generation of matrix on the surface. The nonbiodegradable component provided brief and long-term mechanical support in the site of the lesion. Starting from the viewpoint of interesting mechanical properties, our research group developed PVA-based composite scaffolds for cartilage replacement. This support combined synthetic PVA hydrogel with decellularized cartilage or with a novel and nonspecific biological matrix, namely decellularized Wharton's jelly. Within this composite construct, the ECM derived from decellularization, homogenization, and lyophilization of AC/Wharton's jelly represented the bioactive component which assured the colonization of the scaffold by chondrocytes; on the other hand, PVA offers proper mechanical resistance to the hybrid support. These composite scaffolds revealed an affinity to cartilage in terms of viscoelastic behavior and the ability to sustain chondrocyte adhesion and proliferation [24]. In parallel, we also investigated, for the first time, chemical post-modification of PVA with the important aim of enhancing its biodegradation rate, since the neat polymer in the form of crosslinked hydrogel suffers from poor biodegradation capacity [41,42]. Composite scaffolds made of oxidized PVA (OxPVA) combined with AC/Wharton's jelly acellular matrices were considered as bioactive scaffolds to promote cartilage regeneration in hemophilic arthropathy patients. The biohybrid scaffolds showed adequate mechanical and biological properties for cartilage tissue engineering [25].

Our pioneer studies underlined that, as already known, PVA-based scaffolds present some important limitations for their use in regenerative medicine, while their unique characteristics of biocompatibility and mechanical resistance mean they find application in the biomedical field. Starting from these considerations, the design of hybrid scaffolds which combine PVA with other natural/synthetic materials may represent a step forward in the obtainment of cartilage substitutes which better match the biological and mechanical properties of native tissue.

\section{Design and Fabrication of PVA-Based Hybrid Scaffolds as Cartilage Substitutes}

Among the main limitations of using PVA-based scaffolds in cartilage TE are (i) the low biodegradability after crosslinking [43] and (ii) the scarce propensity to support cell adhesion due the presence of hydrophilic moieties (i.e., hydroxyl groups) on the polymer backbone [17]. Concerning the mechanical performance, despite the fact that PVA hydrogels provide assurance of easily tunable properties in terms of porosity, material stiffness, and elastic modulus, some refinements may still also be needed in this regard.

With the ultimate goal of reinforcing PVA biomimetic properties for cartilage TE, a number of studies in the literature explored the design of biohybrid scaffolds, combining the hydrogel with natural or natural + synthetic materials. PVA-based hybrid scaffolds specifically designed for AC repair are summarized in Tables 1 and 2, considering scaffold components, selected PVA concentrations, and fabrication techniques. 


\subsection{PVA Combined with Natural Materials}

Next-generation PVA-based biomaterials optimized for cartilage TE should combine proper mechanical/tribological behavior with bioactive/bioresorbable features to sustain in vivo regenerative mechanisms (i.e., stimulation of the self-healing capacity of the implant site and the replacement of scaffold with regenerating tissue). To satisfy these needs, PVAbased hybrid scaffolds have been developed by combining the hydrogel with native components of ECM, such as hyaluronic acid [44,45], collagen type I [44,46] or type II [47], and fibrin [44]. These biomolecules appear as appropriate candidates for cartilage TE since they are known to play a vital role in wound-healing processes, assuring that the cell-instructive microenvironment will direct functional regeneration.

To solve the problem of scaffold biocompatibility at the interface with bone tissue, the addition of calcium phosphates (i.e., hydroxyapatite) as bioactive agents was proven to be an effective method to obtain support constructs not only for bone [48] but also for cartilage repair. As a major natural inorganic component of bone, hydroxyapatite was often combined with PVA in order to confer both excellent bioactivity and reinforced mechanical stiffness to the composite scaffold [49-57].

Other natural biomaterials tested for the fabrication of PVA composites as cartilage substitutes are chitosan [58], alginate [59], bacterial cellulose (BC) nanofibers [60], and nanocellulose fibrils (NCF) [61]. Being able to improve the mechanical integrity of the scaffolds and their cell adhesive properties due to the presence of amine groups, chitosan is considered one of the most promising options amongst natural materials for AC replacement [62]. Alginate has been extensively studied for cartilage repair applications by virtue of its appropriate physical features, while nanocellulose - produced by bacteria or obtained by wood pulp-is a nanofibrillar material with an exclusive combination of properties which can be favorable for engineering cartilage-like constructs (i.e., noncytotoxicity and biocompatibility, high flexibility and tensile strength, water-holding capacity) $[61,63]$.

Table 1. Composition and fabrication methods of PVA/natural materials blends for cartilage TE.

\begin{tabular}{|c|c|c|c|}
\hline $\begin{array}{l}\text { Hybrid Scaffold } \\
\text { Components }\end{array}$ & Component Concentrations & Fabrication Technique & Reference \\
\hline $\begin{array}{c}\text { PVA } \\
\text { Hyaluronate } \\
\text { Collagen type I } \\
\text { Fibrin }\end{array}$ & PVA: $12.8 \% w / w$ & $\begin{array}{l}\text { Electrospinning of PVA nanofibers } \\
\text { embedded in biological components }\end{array}$ & [44] \\
\hline $\begin{array}{l}\text { PVA } \\
\text { Hyaluronic acid }\end{array}$ & $\begin{array}{c}\text { PVA: } 5 w t \% \\
\text { Hyaluronic acid: } 2 w t \%\end{array}$ & $\begin{array}{l}\text { Gradual freeze-thawing method: } \\
\text { (1) the composite solution was put in contact } \\
\text { with a surface of } \mathrm{LN}_{2} \text { for } 30 \text { min at } \mathrm{RT} \text { to } \\
\text { enable gradual freezing from the bottom } \\
\left(\mathrm{LN}_{2} \text { side) to the top }\right. \\
\text { (2) the sample was subsequently stored at RT } \\
\text { for } 6 \mathrm{~h} \\
\text { (3) the gradual freeze-thawing procedure } \\
\text { was repeated for } 10 \text { cycles }\end{array}$ & [45] \\
\hline $\begin{array}{c}\text { PVA } \\
\text { Collagen type I }\end{array}$ & $\begin{array}{c}\text { PVA: } 10 \% w / v \\
\text { Collagen type I: } 1 \%\end{array}$ & Electrospinning of composite nanofibers & [46] \\
\hline $\begin{array}{c}\text { PVA } \\
\text { Collagen type II }\end{array}$ & $\begin{array}{c}\text { PVA: } 10 \mathrm{wt} \% \\
\text { Collagen type II: } 10 \% w / v \text { added } \\
\text { to PVA in different ratio }\end{array}$ & $\begin{array}{l}\text { Freezing at }-20{ }^{\circ} \mathrm{C} \text { for } 20 \mathrm{~h} / \text { thawing at RT } \\
\text { for } 4 \mathrm{~h} \\
5 \text { thermal cycles }\end{array}$ & [47] \\
\hline
\end{tabular}


Table 1. Cont.

\begin{tabular}{|c|c|c|c|}
\hline $\begin{array}{l}\text { Hybrid Scaffold } \\
\text { Components }\end{array}$ & Component Concentrations & Fabrication Technique & Reference \\
\hline \multirow{7}{*}{$\begin{array}{l}\text { PVA } \\
\text { Hydroxyapatite }\end{array}$} & $\begin{array}{c}\text { PVA: } 11 w^{\circ} \% \\
\text { Hydroxyapatite: not reported }\end{array}$ & $\begin{array}{l}\text { In situ synthesis of hydroxyapatite in PVA } \\
\text { followed by lyophilization }\end{array}$ & [49] \\
\hline & $\begin{array}{c}\text { PVA: not reported } \\
\text { Hydroxyapatite: not reported }\end{array}$ & $\begin{array}{l}\text { In situ synthesis of nanohydroxyapatite } \\
\text { particles in PVA solution } \\
\text { Freezing at }-20^{\circ} \mathrm{C} \text { for } 12 \mathrm{~h} / \text { thawing at RT } \\
\text { for } 6 \mathrm{~h} \\
3,5 \text {, or } 7 \text { thermal cycles }\end{array}$ & {$[50,51]$} \\
\hline & $\begin{array}{c}\text { PVA: } 15 \mathrm{wt} \% \\
\text { Hydroxyapatite: } 3 \text { and } 7.5 \mathrm{wt} . \%\end{array}$ & $\begin{array}{l}\text { In situ synthesis of nanohydroxyapatite } \\
\text { Freezing at }-18^{\circ} \mathrm{C} \text { for } 12 \mathrm{~h} / \text { thawing at } 25^{\circ} \mathrm{C} \\
\text { for } 12 \mathrm{~h} \\
3 \text { thermal cycles }\end{array}$ & [52] \\
\hline & $\begin{array}{l}\text { PVA: } 77.6 \mathrm{~g} \text { in } 220 \mathrm{~mL} \mathrm{dH}_{2} \mathrm{O} \\
\text { Hydroxyapatite: not reported }\end{array}$ & $\begin{array}{l}\text { Layer-by-layer casting method } \\
\text { Freezing at }-20^{\circ} \mathrm{C} \text { for } 12 \mathrm{~h} / \text { thawing at RT } \\
\text { for } 10 \mathrm{~h} \\
\text { Repeated thermal cycles }\end{array}$ & [53] \\
\hline & $\begin{array}{c}\text { PVA: } 15 w \mathrm{t} \% \\
\text { Hydroxyapatite: } 1.5,3,6 \text { and } \\
7.5 w \mathrm{t} \%\end{array}$ & $\begin{array}{l}\text { Freezing at }-18{ }^{\circ} \mathrm{C} \text { for } 1 \mathrm{~h} / \text { thawing at } 25^{\circ} \mathrm{C} \\
\text { for } 1 \mathrm{~h} \\
3 \text { thermal cycles }\end{array}$ & [54] \\
\hline & $\begin{array}{l}\text { PVA: } 15 \% \\
\text { Hydroxyapatite: } 3 \% \\
\mathrm{dH}_{2} \mathrm{O}: 82 \%\end{array}$ & $\begin{array}{l}\text { Freezing at }-20^{\circ} \mathrm{C} \text { for } 6-10 \mathrm{~h} / \text { thawing at RT } \\
\text { for } 2-3 \mathrm{~h} \\
9 \text { thermal cycles } \\
\mathrm{F} / \mathrm{T} \text { served for the crosslinking of the } \\
\text { composite scaffold on UHMWPE acetabulum }\end{array}$ & {$[55,56]$} \\
\hline & $\begin{array}{c}\text { PVA: } 10 w \mathrm{t} \% \\
\text { Hydroxyapatite: not reported }\end{array}$ & $\begin{array}{l}\text { Directional freeze-thaw process to form the } \\
\text { PVA hydrogel } \\
\text { Gel electrophoresis method for the } \\
\text { dispersion of hydroxyapatite particles } \\
\text { within PVA }\end{array}$ & [57] \\
\hline $\begin{array}{c}\text { PVA } \\
\text { Chitosan }\end{array}$ & $\begin{array}{l}\text { PVA: } 10 \% \text { weight ratio } \\
\text { Chitosan: added to PVA in } \\
\text { various proportion }\end{array}$ & $\begin{array}{l}\text { Freezing at }-20{ }^{\circ} \mathrm{C} \text { for } 20 \mathrm{~h} / \text { thawing at } \mathrm{RT} \\
\text { for } 8 \mathrm{~h} \\
7 \text { thermal cycles }\end{array}$ & [58] \\
\hline $\begin{array}{l}\text { PVA } \\
\text { Alginate }\end{array}$ & $\begin{array}{l}\text { PVA: } 10 \% \text { or } 20 \% w / v \text { solution } \\
\text { Alginate: microspheres formed } \\
\text { using a standard water-in-oil } \\
\text { emulsification technique }\end{array}$ & $\begin{array}{l}\text { Freezing at }-25^{\circ} \mathrm{C} \text { for } 23 \mathrm{~h} / \text { thawing at } 25^{\circ} \mathrm{C} \\
\text { for } 1 \mathrm{~h} \\
5 \text { thermal cycles }\end{array}$ & [59] \\
\hline \multirow[t]{2}{*}{$\begin{array}{c}\text { PVA } \\
\text { Nanocellulose }\end{array}$} & $\begin{array}{c}\text { PVA: } 10 w t \% \\
\text { BC: } 0.30 \text { and } 0.85 w t \%\end{array}$ & $\begin{array}{l}\text { Freezing at }-20^{\circ} \mathrm{C} / \text { thawing at } 20^{\circ} \mathrm{C} \\
0.1^{\circ} \mathrm{C} / \mathrm{min} \text { freeze-thawing rate } \\
1,3,6 \text { thermal cycles }\end{array}$ & {$[60]$} \\
\hline & $\begin{array}{c}\text { PVA: } 10 w t \% \\
\text { NCF: } 2,6,10,14 w t \%\end{array}$ & $\begin{array}{l}\text { Ultrasonication, degas and drying at } 70{ }^{\circ} \mathrm{C} \\
\text { for } 4 \mathrm{~h}\end{array}$ & [61] \\
\hline $\begin{array}{c}\text { PVA } \\
\text { Human cartilage ECM } \\
\text { Wharton's jelly ECM }\end{array}$ & $\begin{array}{l}\text { PVA: } 16 \% \text { and } 25 \% w / w \\
\quad \text { ECM: } 1 \mathrm{~g} / 15 \mathrm{~mL}\end{array}$ & $\begin{array}{l}\text { Freezing at }-20^{\circ} \mathrm{C} \text { for } 24 \mathrm{~h} / \text { thawing at } \\
-2.5^{\circ} \mathrm{C} \text { for } 24 \mathrm{~h} \\
5 \text { thermal cycles }\end{array}$ & {$[24,25]$} \\
\hline $\begin{array}{c}\text { PVA } \\
\text { Demineralized bone matrix }\end{array}$ & $\begin{array}{l}\text { PVA: } 1,5,10,15,20,25,30,40 \% \\
\text { Bone matrix: } 0.35 \mathrm{~g} / \mathrm{mL}\end{array}$ & $\begin{array}{l}\text { Mixing DBM into PVA solutions to obtained } \\
\text { injectable composite hydrogels }\end{array}$ & [64] \\
\hline
\end{tabular}


Table 1. Cont.

\begin{tabular}{|c|c|c|c|}
\hline $\begin{array}{l}\text { Hybrid Scaffold } \\
\text { Components }\end{array}$ & Component Concentrations & Fabrication Technique & Reference \\
\hline $\begin{array}{c}\text { PVA } \\
\text { Amino acids }\end{array}$ & $\begin{array}{c}\text { PVA: } 4 \mathrm{wt} \% \\
\text { Amino acids: varied from } \\
5 \text { to } 20 \mathrm{wt} \% \text { and optimized at } \\
10 \mathrm{wt} \%\end{array}$ & In situ crosslinking by citric acid & {$[65]$} \\
\hline $\begin{array}{c}\text { PVA } \\
\text { Acrylamide }\end{array}$ & $\begin{array}{c}\text { PVA: } 15 \%(w / w) \\
\text { Acrylamide: } 5,10,15 \%(w / w)\end{array}$ & $\begin{array}{l}\text { Freezing at }-17^{\circ} \mathrm{C} \text { for } 16 \mathrm{~h} / \text { thawing for } 8 \mathrm{~h} \\
2 \text { thermal cycle separated by an } 8 \mathrm{~h} \\
\text { polymerization process }\end{array}$ & {$[34]$} \\
\hline \multicolumn{4}{|c|}{$\begin{array}{l}\text { Abbreviations: } \mathrm{BC} \text {, bacterial cellulose; } \mathrm{DBM} \text {, demineralized bone matrix; } \mathrm{dH}_{2} \mathrm{O} \text {, deionized water; } \mathrm{ECM} \text {, extracellular matrix; } \mathrm{F} / \mathrm{T} \\
\text { thawing; h, hours; } \mathrm{LN}_{2} \text {, liquid nitrogen; } \mathrm{NCF} \text {, nanocellulose fibrils; PVA, polyvinyl alcohol; } \mathrm{RT} \text {, room temperature; } w / v \text {, weight per } \\
w / w \text {, weight per weight; wt } \% \text {, weight percent. }\end{array}$} \\
\hline Hybrid Scaffold Components & Component Concentrations & Fabrication Technique & Reference \\
\hline $\begin{array}{l}\text { PVA } \\
\text { Hydroxyapatite } \\
\text { PAA }\end{array}$ & $\begin{array}{l}\text { PVA: } 10 \%, 12 \%, 14 \%, 16 \% \\
\text { Hydroxyapatite: } 2 \%, 2.5 \%, 3 \% \\
\text { PAA: } 3 \%, 4 \%, 5 \%\end{array}$ & $\begin{array}{c}\text { Freezing at }-20{ }^{\circ} \mathrm{C} \text { for } 12 \mathrm{~h} / \text { thawing at } \mathrm{RT} \text { for } 6 \mathrm{~h} \\
\text { Repeated thermal cycles } \\
\text { PEG dehydration } \\
\text { Annealing treatment }\end{array}$ & {$[66]$} \\
\hline $\begin{array}{l}\text { PVA } \\
\text { Hydroxyapatite } \\
\text { PLGA }\end{array}$ & Not reported & $\begin{array}{c}\text { Solvent extraction, evaporation technique } \\
\text { Freezing at }-20{ }^{\circ} \mathrm{C} \text { for } 21 \mathrm{~h} / \text { thawing at RT for } 3 \mathrm{~h} \\
5 \text { thermal cycles }\end{array}$ & {$[67]$} \\
\hline $\begin{array}{l}\text { PVA } \\
\text { Hydroxyapatite } \\
\text { HACC }\end{array}$ & $\begin{array}{c}\text { PVA: } 15 \% w / v \\
\text { Hydroxyapatite: } 2 \%, 3 \%, 4 \% w / v \\
\text { HACC: } 5 \% w / v\end{array}$ & $\begin{array}{c}\text { Freezing at }-20{ }^{\circ} \mathrm{C} \text { for } 12 \mathrm{~h} / \text { thawing at } 25^{\circ} \mathrm{C} \text { for } \\
12 \mathrm{~h} \\
3 \text { thermal cycles } \\
\text { Immersion in } \mathrm{Na}_{3} \mathrm{Cit} \text { for dual physical crosslinking }\end{array}$ & {$[68]$} \\
\hline $\begin{array}{l}\text { PVA } \\
\text { Hydroxyapatite } \\
\text { GO }\end{array}$ & $\begin{array}{l}\text { PVA: } 5,16,20,25 \mathrm{wt} \% \\
\text { Hydroxyapatite: } 10 \mathrm{mg} / \mathrm{mL} \\
\text { GO: } 2.88 \mathrm{mg} / \mathrm{mL}\end{array}$ & $\begin{array}{c}\text { Extrusion 3D printing technique } \\
\text { Freezing at }-20^{\circ} \mathrm{C} \text { for } 12 \mathrm{~h} / \text { thawing at RT for } 4 \mathrm{~h} \\
4 \text { thermal cycles }\end{array}$ & {$[69]$} \\
\hline $\begin{array}{l}\text { PVA } \\
\text { Chitosan } \\
\text { GO }\end{array}$ & $\begin{array}{l}\text { PVA: } 20 \mathrm{wt} \% \\
\text { Chitosan: } 8 \% \text { weight } \\
\text { GO: } 20 \mathrm{mg} / \mathrm{mL}\end{array}$ & $\begin{array}{c}\text { Electron beam lithography treatment to produce } \\
\text { chitosan solution } \\
\text { Chemical crosslinking with glyoxal of } \\
\text { PVA/chitosan solution } \\
\text { Electrospinning of the final } \\
\text { PVA/chitosan/GO blend }\end{array}$ & {$[70]$} \\
\hline $\begin{array}{c}\text { PVA } \\
\text { Alginate } \\
\text { Bioglass }{ }^{\circledR}\end{array}$ & $\begin{array}{l}\text { PVA: } 10,20,30 \mathrm{~g} / \mathrm{L} \\
\text { Alginate: } 2 \mathrm{~g} / \mathrm{L} \\
\text { Bioglass }^{\circledR}: 10 \mathrm{~g} / \mathrm{L}\end{array}$ & $\begin{array}{c}\text { Preparation of homogenous composite suspension } \\
\text { by ultrasonication } \\
\text { Electrophoretic deposition process of } \\
\text { PVA/alginate/BG coatings on stainless steel }\end{array}$ & {$[71]$} \\
\hline $\begin{array}{l}\text { PVA } \\
\text { Alginate } \\
\text { PEGDA }\end{array}$ & $\begin{array}{l}\text { PVA: } 10 \% w / v \\
\text { Alginate: } 10 \% w / v \\
\text { PEGDA: } 10 \% w / v \\
\text { I-2959: } 0.05 \% w / v\end{array}$ & $\begin{array}{l}\text { 3D bioprinting with simultaneous } \\
\text { photopolymerization under UV light }\end{array}$ & {$[72]$} \\
\hline $\begin{array}{l}\text { PVA } \\
\text { Chondroitin sulfate } \\
\text { PEGDA }\end{array}$ & $\begin{array}{l}\text { PVA: not reported } \\
\text { Chondroitin sulfate: } 10 \% w / v \\
\text { PEGDA: } 10 \% w / v\end{array}$ & Photocrosclinking with olycidyl methacrylate & [17] \\
\hline $\begin{array}{l}\text { PVA } \\
\text { Hyaluronic acid } \\
\text { PEGDA }\end{array}$ & $\begin{array}{l}\text { PVA: not reported } \\
\text { Hyaluronic acid: } 1 \% w / v \\
\text { PEGDA: } 10 \% w / v\end{array}$ & Photocrosslinking with glycidyı methacrylate & {$[17]$} \\
\hline $\begin{array}{l}\text { PVA } \\
\text { Bone } \\
\text { BG }\end{array}$ & $\begin{array}{c}\text { PVA: } 20 \%(w / w) \\
\text { Pig spongy bone: not reported } \\
\text { BG: } 4 \%, 8 \% \text { weight ratio with respect } \\
\text { to PVA }\end{array}$ & $\begin{array}{c}\text { Freezing at }-20{ }^{\circ} \mathrm{C} \text { for } 8-12 \mathrm{~h} / \text { thawing at } \mathrm{RT} \text { for } \\
4-6 \mathrm{~h} \\
4 \text { thermal cycles }\end{array}$ & {$[73]$} \\
\hline
\end{tabular}

Abbreviations: BG, bioactive glass; GO, graphene oxide; h, hours; HACC, 2-hydroxypropyltrimethyl ammonium chloride chitosan; I-2959 Irgacure $^{\mathrm{TM}} 2959 ; \mathrm{Na}_{3} \mathrm{Cit}$, trisodium citrate; PAA, polyacrylic acid; PEG, polyethylene glycol; PEGDA, poly(ethylene glycol) diacrylate; PLGA, poly(lactic-co-glycolic acid); PVA, polyvinyl alcohol; RT, room temperature; $w / v$, weight per volume; wt $\%$, weight percent. 
To develop PVA-based scaffolds provided with better chondrogenic microenvironment, some studies also investigated the effects of decellularized ECM in combination with synthetic hydrogel, using acellular human cartilage $[24,25]$ or demineralized bone matrix (DBM) [64].

Finally, additional composite scaffolds designed for cartilage TE include PVA blends with amino acids (AA) such as glycine, lysine, and phenylalanine, which improve osteointegration and antibacterial activity [65] and interpenetrated polymer networks (IPNs) obtained by polymerizing acrylamide in the pores of the PVA hydrogel [34] to prevent loss of lubricity, pore collapse, and loss of water content during the scaffold manufacturing process (Table 1).

\subsection{PVA Combined with Natural and Synthetic Materials}

A smaller group of reviewed papers described the conceptualization, manufacturing, and mechanical characterization of hybrid scaffolds for cartilage repair which mixed PVA not only with natural but also with other synthetic materials (Table 2).

Within the hybrid supports, the combination of PVA with natural materials was generally taken into consideration to augment the bioactivity of the polymer. On the other hand, enriching the composite with another synthetic counterpart was mainly thought to implement the mechanical features of the resulting cartilage substitute.

As for PVA/natural material blends, the majority of works focused on PVA/ hydroxyapatite-based composites enriched with different synthetic materials, such as polyacrylic acid (PAA) [66], poly(lactic-co-glycolic acid) (PLGA) [67], 2-hydroxypropyltrimethyl ammonium chloride chitosan (HACC) [68] and graphene oxide (GO) [69]. Graphene oxide was also tested in combination with PVA/chitosan-based scaffolds [70], while PVA/alginate-based composites were fabricated with the addition of bioactive glass (BG) Bioglass ${ }^{\circledR}$ [71] or poly(ethylene glycol) diacrylate (PEGDA) [72]. This synthetic material was also used to fabricate cartilage-like supports based on PVA/chondroitin sulfate and PVA/hyaluronic blends [17], whereas a peculiar kind of BG/PVA/pig bone composite implant has been designed and investigated as cartilage replacement [73].

Similarly to PVA, PAA is a hydrophilic polymer which can be obtained in the form of active hydrogel for biomedical applications [74], whereas PLGA use is rather consolidated for the fabrication of scaffolds mimicking AC owing to its favorable mechani$\mathrm{cal} /$ biodegradation characteristics and capacity to sustain drug delivery for chondrogenesis stimulation purposes [75].

The water-soluble chitosan derivative HACC exhibits excellent antibacterial ability and good biocompatibility, which render it a promising candidate material to produce tissue-engineered scaffolds [76].

In the biomedical field, GO can be exploited for its ability to form layer-by-layer agglomerates through interplanar interactions. Based on that, the coating of polymer matrices with single-layered GO dispersion can be performed to prepare GO/polymer composite materials for $\mathrm{AC}$ regeneration [70].

Bioactive glass coatings combined with PVA revealed encouraging features for their application in the orthopedic field, showing improvement of the bioactivity and interface properties of implants and helping to create a firm interface joint between the surface of the bone and the cartilage substitute [73].

Finally, PEGDA has recently emerged as a biologically inert hydrogel with hydrophilic, elastic, and tunable mechanical properties which can be combined to cell-adhesive biomaterials for different TE applications [72].

\subsection{Fabrication Techniques}

In the design of composite scaffolds, tailorable fabrication methods based on the use of different polymer concentrations and manufacturing technologies play a key role in defining the final biological/mechanical features of the supports. 
The physical crosslinking by freeze-thawing cycles is the elective and more biosafe method to produce PVA-based hydrogels with customized mechanical performance. Indeed, varying the number of freeze-thawing cycles, the cooling-thawing rate and the incubation times at lower/higher temperatures, it is possible to strongly control the structure properties of the resulting crosslinked polymer, modulating the density of polymer networks [77].

The freeze-thawing method was used to fabricate PVA/collagen type II/chondroitin sulfate hybrid supports by mixing the natural powders to PVA solutions which underwent cooling-thawing cycles and final lyophilization to form porous scaffolds [47]. Gradual freeze-thawing cycles (i.e., gradual freezing of the composite solution from the bottom to the top and then thawing of the sample) were performed to obtain PVA/hyaluronic acid hybrid scaffolds with a wide range of stiffness gradients. To this end, a liquid nitrogen $\left(\mathrm{LN}_{2}\right)$-contacting gradual freezing-thawing method without the use of any additives or specific devices was standardized to produce the composite hydrogels [45].

For the fabrication of PVA/hydroxyapatite composites, calcium phosphates were added to PVA aqueous solution at the desired concentration and, after casting into molds, freeze-thawing cycles allowed for the obtainment of the compound hydrogels. Stiffness gradient scaffolds were produced by varying hydroxyapatite concentration $[52,54]$. Other authors described the manufacturing of nanohydroxyapatite/PVA gel composites by in situ synthesis of nano-HA particles in PVA solution followed by lyophilization [49] or freeze-thawing cycles $[50,51]$ to accomplish polymer crosslinking. Interestingly, Yusong and colleagues [53] reported the preparation of multilayer gradient hydroxyapatite/PVA hydrogels through layer-by-layer casting technology combined with freeze-thaw cycle method. In brief, the composite solutions with different hydroxyapatite concentrations were firstly prepared using an in situ synthesis method. Then, the hydroxyapatite/PVA aqueous solutions were multilayered on molds starting from the more highly concentrated to the less concentrated, freezing each layer before adding the next one. Finally, the multilayered solutions underwent crosslinking by freeze-thawing cycles. With the similar scope to obtain in situ synthesis of bi-layered gradient PVA/hydroxyapatite composites, $\mathrm{Su}$ and collaborators [57] resorted to the directional freeze-thaw (DFT) and electrophoresis method. The DFT process allowed unidirectionally freezing the PVA solution with the solvent crystals aligned along the freezing direction, obtaining aligned porose structures. The PVA was frozen in liquid nitrogen and thawed at room temperature (RT) for repeated DFT cycles. The hydroxyapatite particles were in situ synthetized and then dispersed into the PVA hydrogel using the electrophoresis process, which allowed obtaining a bi-layered gradient composite containing hydroxyapatite particles in only half of the gel region.

To create a model for torsional friction, tribological, and fluid load support studies, PVA/hydroxyapatite composites were crosslinked on ultrahigh molecular weight polyethylene (UHMWPE) acetabulum through a chemical grafting and freeze-thawing method $[55,56]$. Simulating the prosthesis/bone interface, this system provided a theoretical basis for the study of artificial joint repair materials.

PVA/chitosan and PVA/alginate blends were both prepared by the freeze-thawing method. In the first case, the chitosan powder was mixed with the PVA solution on a magnetic blender until complete dissolution, and the mixture was then vacuum-dried and degassed. The obtained composite solution was finally poured into molds and subjected to freeze-thawing cycles [58]. For PVA/alginate scaffold production, alginate microspheres were formed using a standard water-in-oil emulsification technique. Subsequently, the microspheres were added to PVA aqueous solution and mixed under stirring. The final emulsions were poured into molds and subjected to freeze-thawing cycles [59].

The fabrication of PVA/nanocellulose composites involved two main techniques to obtain composite hydrogel supports: ultrasonication and freeze-thawing. In particular, PVA/NCF composites were manufactured as $0.1 \mathrm{~mm}$ thick films by mixing an aqueous PVA solution with NCF water suspension and then favoring nanocellulose fibril dispersion via ultrasonic treatment for approximately $5 \mathrm{~min}$ at a power level of $85 \%$. The blends were 
degassed in a desiccator at RT until films were formed. The final films were obtained by drying samples at $70{ }^{\circ} \mathrm{C}$ [61]. On the other hand, preparation of PVA/BC hybrid scaffolds was accomplished firstly by preparing the homogenized BC suspension by fermentation using the bacteria Acetobacter xylinum. Solid PVA powder was then added to the BC suspension to obtain the required solution composition. After transferring PVA/BC solutions into aluminum molds, a heated/refrigerated circulator was used to perform multiple freeze-thawing cycles and produce the final scaffolds [60,78].

Bodugoz-Senturk and co-workers [34] prepared PVA/acrylamide composites by polymerizing acrylamide monomer in a physically crosslinked PVA network formed by the freeze-thawing method. The authors aimed to improve scaffold mechanical strength without resorting to thermal annealing, which is known to affect hydrogel lubricity because it leads to pore collapse and water content reduction. This could cause an increase in coefficient of friction that would augment the risk of cartilage damage.

To the best of our knowledge, only a few studies in the literature were found to consider the design of PVA/ECM composites for cartilage TE. As already described, our research group published, for the first time, a cost-effective and reproducible method to realize biohybrid scaffolds formed by a thin layer of decellularized, homogenized, and freeze-dried human Wharton's jelly or AC matrix crosslinked by freeze-thawing on PVA hydrogels [24,25] (Figure 3). ECM homogenates are an innovative manner of working with biological matrices, which can be molded and tailored according to shape and size. Furthermore, the lyophilization process make the ECM easy to store. Physical crosslinking of lyophilized ECM with PVA solutions led to three-dimensional (3D) composite scaffolds where the biological matrix provided a supportive biomimetic microenvironment for chondrocytes, whereas the hydrogel ensured adequate mechanical support. Besides the manufacture of these 3D PVA/ECM supports, Dadgar and colleagues [64] investigated the possibility to produce injectable PVA-based composite scaffold for in vivo cartilage tissue regeneration. DBM powder was suspended in solutions with different concentrations of wt \% PVA to identify the most appropriate injectable formulation.
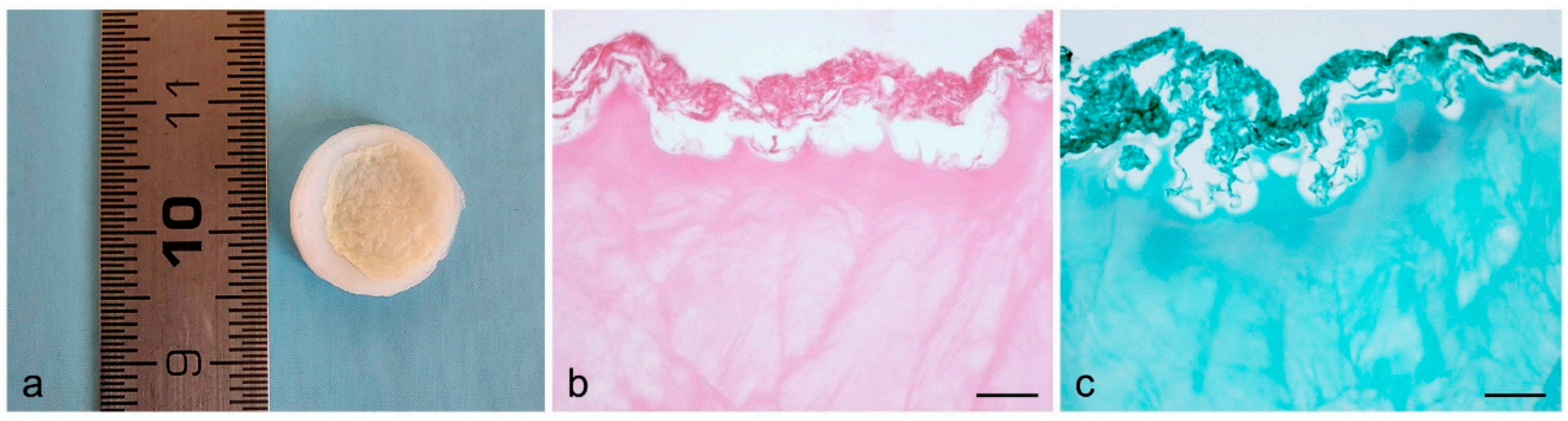

Figure 3. Gross appearance (a) and histological morphology $(\mathbf{b}, \mathbf{c})$ of PVA/AC composite scaffolds after hematoxylin and eosin (b) and Masson's trichrome (c) staining. Human AC was decellularized, homogenized, and lyophilized to obtain a thin matrix layer which was crosslinked onto PVA scaffold by freeze-thawing. Scale bar: $50 \mu \mathrm{m}$.

Concerning PVA-based hybrid scaffolds combined with synthetic materials, crosslinking by freeze-thawing was one of the most used methods for integrating the different components and obtaining stable hydrogel supports for cartilage repair.

PVA/hydroxyapatite/PAA composite hydrogels were prepared by the freeze-thawing method, with polyethylene glycol (PEG) dehydration and annealing treatment. Briefly, different concentrations of PVA, hydroxyapatite, and PAA were mixed by stirring at $90{ }^{\circ} \mathrm{C}$ and the mixture then underwent repeated freeze-thawing cycles before being dehydrated by immersion in PEG solution and treated with different annealing temperatures. At last, samples were rehydrated in distilled water to obtain the composite hydrogels [66]. 
Resorting to the solvent extraction, evaporation technique, and repeated freezethaw cycling method, a double-layer PVA/hydroxyapatite hydrogel coated with PLGA/ hydroxyapatite/PVA scaffold was manufactured to resemble the complex structure and function of AC. The core, consisting of PVA/hydroxyapatite hydrogel, had the primary role of bearing the mechanical load. The peripheral component formed by PLGA/ hydroxyapatite/PVA was designed to facilitate the interaction with surrounding cartilage at the implant site [67]. This bi-layered composite was produced by incorporating PVA and nanohydroxyapatite into distilled water at high temperature $\left(90^{\circ} \mathrm{C}\right)$ and under stirring. The blend was then added with PLGA and the PLGA/hydroxyapatite/PVA solution was first stirred to evaporate the dichloromethane in which PLGA was dissolved and then cast into molds before performing freeze-thawing cycles.

Hybrid PVA/bone scaffolds was enriched with BG suspension in ethanol, which was mixed into PVA solution by ultrasonication. After heating the blend at $110{ }^{\circ} \mathrm{C}$, it was poured into molds where pig spongy bone was previously placed. As the last step, freeze-thawing cycles were performed to integrate the synthetic and natural counterparts and produce the final composite hydrogel [73].

Dual physical crosslinking by thermal cycles and treatment with trisodium citrate $\left(\mathrm{Na}_{3} \mathrm{Cit}\right.$ ) was described by Gan and collaborators [68] to fabricate double-network (DN) hydrogels composed of PVA, hydroxyapatite, and HACC. The hydroxyapatite and HACC were dissolved in PVA aqueous solution by stirring at $70^{\circ} \mathrm{C}$, and the mixture was degassed and crosslinked by freeze-thawing. The resulting composite was finally soaked into $\mathrm{Na}_{3} \mathrm{Cit}$ to obtain the DN hydrogel named PVA/hydroxyapatite/HACC-Cit.

Besides physical crosslinking, the use of chemical agents was also reported to obtain the integration of PVA hydrogels with natural additives. In this regard, Mohanapriya and Raj [65] described, for the first time, the fabrication of PVA/AA biocomposite films by solution-casting technique and in situ crosslinking with citric acid (CT). After mixing the PVA and the AA (i.e., glycine, lysine, and phenyl alanine) solutions under stirring, $10 \mathrm{wt} \%$ of CT in relation to PVA was added to the mixture as crosslinker. The viscous solution was cast on a flat Plexiglass plate and a $\sim 120 \mu \mathrm{m}$ thick membrane was formed by evaporating the solvent at RT.

A stepwise fabrication method was described by Kim and collaborators [17] to produce a PVA-based hybrid scaffold with dual functionalities as a biomechanically reinforced and a biochemically cartilage-mimicking support. Within the scaffold, macroporous PVA sponges served as a base structure which provided elastic reinforcement and 3D interconnected pores to favor mass transfer and cell infiltration. PVA internal pores were then filled with photocrosslinkable cartilage-specific bioactive components (i.e., chitosan and hyaluronic acid treated with glycidyl methacrylate and combined with PEGDA) in which rabbit chondrocytes were previously photo-encapsulated.

Amongst the different reported methods to obtain biomimetic material for tissue regeneration, use of the electrophoretic deposition (EPD) process is also spreading in the orthopedic field for the low-cost fabrication of nanocomposite coatings which can enhance biomaterial performance. In this regard, an increasing number of TE studies are considering the modification of orthopedic implants with biological coatings containing bioceramics, biopolymers, and biomolecules which can improve the biocompatibility and bone-to-implant contact as well as reduce the risk of infections [79]. In the field of PVA-based composite materials, Chen and co-workers [71] reported the enrichment of $\mathrm{PVA} /$ alginate blends with BG in order to produce bioactive polymer/ceramic coatings on stainless steel by a single-step electrophoretic deposition (EPD) process. PVA/alginate/BG suspension was produced by first mixing PVA aqueous solution with alginate powders through stirring and ultrasonication. After that, the same procedures were used to mix this composite with BG powder. EPD onto stainless steel foils was then performed, setting the optimal range of voltages (5-30 V) and deposition times (2-60 s) to fabricate coatings with high homogeneity, free of cracks, and with adequate deposit yields [71]. 
Aside from physical-chemical crosslinking, the electrospinning of PVA solution has been extensively studied so far for the preparation of polymer fibers with diameters in the nano-/micrometer scale [80], which offers unique possibilities of tuning scaffold surface to promote cell adhesive/instructive properties. In the field of cartilage TE, the electrospinning technique was one of the methods reported for fabricating PVA-based composite supports. For example, Filovà and colleagues [44] described the fabrication of electrospun PVA nanofibers blended with liposomes, enriched with basic fibroblast growth factor (bFGF) and insulin and then embedded in a hyaluronate/collagen type I/fibrin composite hydrogel. This technique allowed production of a novel drug delivery system based on the intake effect of liposomes encapsulated in PVA nanofibers [44]. The electrospinning technique was also employed by Lin and collaborators [46] to fabricate two types of bi-layered PVA/collagen type I composites which replicated the superficial and transitional zones of AC. To this end, aligned and random nanofibers were electrospun onto a freeze-dried collagen sponge to obtain the aligned and random composite supports, respectively.

Fabrication of PVA/chitosan/GO nanofibers was accomplished by Cao and coworkers [70] by a combination of chemical crosslinking and electrospinning techniques. A homogenous PVA/chitosan solution was chemically crosslinked by the use of glyoxal and then mixed with GO dispersion by stirring. The resulting mixture was finally electrospun to obtain composite nanofibers.

Notably, advanced technologies of additive manufacturing technique by 3D printing were also recently described for the fabrication of PVA-based hybrid scaffolds for cartilage replacement [69,72]. In an attempt to repair AC with polymer hydrogels, 3D printing presents the important advantage of realizing individualized and customized scaffolds which can perfectly fit with the damage site. Using polymer hydrogels such as PVA, which possess physical-chemical properties closely resembling those of human AC, engineered cartilage substitutes with high structural complexity and design flexibility can be realized by 3D printing. Taking advantage of this technology, PVA/alginate/PEGDA hydrogel was prepared starting from a PVA solution mixed with alginate powder and supplemented with PEGDA and I-2959 to provide cytocompatible photo-initiating conditions. The composite hydrogel was allowed to homogenize at RT overnight, and then 3D printing of the scaffold was carried out with simultaneous photopolymerization under UV light [72].

A combination of 3D printing technology and freeze-thawing was described by Meng and colleagues [69] to produce PVA/hydroxyapatite/GO nanocomposite hydrogels. Firstly, the composite solution was prepared by sonicating GO into deionized water and adding PEG and hydroxyapatite before further mixing by sonication. Afterwards, PVA was added to the solution and mixed by stirring at $95^{\circ} \mathrm{C}$. This PVA-based solution was used as printing ink, and the 3D printing process was performed via the microextrusion printing technique using a 3D bioprinter. The preformed samples finally underwent the freeze-thawing process to obtain 3D-printed PVA-based nanocomposite hydrogel.

\section{Mechanical Properties of PVA-Based Hybrid Scaffolds}

The rationale behind the conceptualization of scaffolds for cartilage TE is to provide a biomimetic environment to match healthy tissue biomechanics while preserving an interconnected pore network for cell migration and the efficient exchange of nutrients and wastes [81]. From the perspective of in vivo implant inside the joint, cartilage substitutes are required to be capable of withstanding loading/compression/tensile forces, frictional drag, as well as lubrication and swelling phenomena. Thus, one of the most challenging issues is that scaffolds need to match not a single mechanical parameter, such as modulus or strength, but the numerous and complex viscoelastic, nonlinear, and anisotropic mechanical properties of cartilage tissue [28].

Remarkably, intriguing possibilities for tissue regeneration therapies are emerging due to the growing awareness that the mechanical properties of the scaffold may affect the behavior of interacting cells, stimulating stem cell growth and differentiation as well as directing lineage-specific cell fate decisions and the development of functional cell 
phenotype [82]. Tissue-specific cells have also been demonstrated to sense the stiffness of the substrate, modulating their morphological and adhesive features in response to mechanical cues. Furthermore, scaffold stiffness has also been demonstrated to have a role in regulating cell migration, guiding the infiltration of host tissue cells [83].

For these reasons, after scaffold design and fabrication, the investigation of their mechanical behaviors may require a significant amount of in vitro testing to verify their suitability for use as cartilage replacements.

\subsection{Biomechanical Tests Performed on Composite Scaffolds}

Regarding PVA-based hybrid scaffolds designed for cartilage TE, most of the reviewed papers described the analysis of the specific mechanical properties by compression tests $[17,44,45,47,51-54,57,58,60,64,66-69,72,73]$ and tensile tests $[17,24,25,46,47,49,51,52,54,57,58,61,64,65,67,68,70,72]$, including Young's modulus calculation $[17,44,61,66,73]$. A certain interest was also paid to the definition of friction properties $[34,52,54-56,66,69]$ and stress relaxation characteristics $[59,60,66]$ (Table 3).

Table 3. Mechanical tests performed on PVA-based composite scaffolds designed for cartilage TE.

\begin{tabular}{|c|c|c|c|}
\hline Mechanical Test & Description & Outcome Measures & References \\
\hline Compression test & $\begin{array}{l}\text { Assessment of the } \\
\text { load-bearing capacity of the } \\
\text { scaffolds by simulating the } \\
\text { application of compressive } \\
\text { load in the joint }\end{array}$ & $\begin{array}{l}\text { - Stress-strain curves } \\
\text { - Compressive elastic modulus } \\
\text { (stiffness) determined from } \\
\text { the stress-strain curves } \\
\text { - Shear modulus } \\
\text { - Compressive strength } \\
\text { - Stress-at-break }\left(\sigma_{\max }\right) \\
\text { - Strain-at-break }(\varepsilon) \\
\text { - Ultimate compressive stress }\end{array}$ & $\begin{array}{c}{[17,44,45,47,51-54,57,58,60,64,66-} \\
69,72,73]\end{array}$ \\
\hline Tensile test & $\begin{array}{l}\text { Evaluation of scaffold } \\
\text { response to tensile loads } \\
\text { which simulate shear stress }\end{array}$ & $\begin{array}{l}\text { - Stress-strain curves } \\
\text { - Young's modulus } \\
\text { - Tensile strength } \\
\text { - Stress-at-break }\left(\sigma_{\max }\right) \\
\text { - Strain-at-break }(\varepsilon) \\
\text { - Ultimate tensile stress } \\
\text { - Ultimate tensile strength } \\
\text { - Toughness }\end{array}$ & $\begin{array}{c}{[17,24,25,46,47,49,51,52,54,57,58} \\
61,64,65,67,68,70,72]\end{array}$ \\
\hline Friction test & $\begin{array}{l}\text { Investigation of scaffold } \\
\text { suitability to provide an ideal } \\
\text { interface between bones by } \\
\text { minimize frictional drag }\end{array}$ & $\begin{array}{l}\text { - Friction coefficient } \\
\text { - Friction torque-angular } \\
\text { displacement (T- } \theta \text { ) curve } \\
\text { - Average friction torques and } \\
\text { friction coefficients } \\
\text { under different loads } \\
\text { - Swing friction coefficient } \\
\text { - Torsion friction coefficient } \\
\text { - Sliding friction coefficient } \\
\text { - Rotation friction }\end{array}$ & {$[34,52,54-56,66,69]$} \\
\hline Stress relaxation test & $\begin{array}{l}\text { Simulation of the } \\
\text { physiological condition of } \\
\text { cartilage tissue when a } \\
\text { constant deformation is } \\
\text { applied due to the hydraulic } \\
\text { pressure, which is reduced } \\
\text { after liquid flow }\end{array}$ & $\begin{array}{l}\text { - Elastic modulus } \\
\text { - Poisson's ratio }(v) \\
\text { - Aggregate modulus }\left(\mathrm{H}_{\mathrm{a}}\right) \\
\text { - Dynamic modulus }\left(\mathrm{E}_{\mathrm{D}}\right) \\
\text { - Stress relaxation curve }\end{array}$ & {$[59,60,66]$} \\
\hline
\end{tabular}


Table 3. Cont.

\begin{tabular}{|c|c|c|c|}
\hline Mechanical Test & Description & Outcome Measures & References \\
\hline Dynamic mechanical tests & $\begin{array}{l}\text { Assessment of the viscoelastic } \\
\text { properties of the composite } \\
\text { scaffold }\end{array}$ & $\begin{array}{l}\text { - Elastic modulus } \\
\text { - Storage modulus } \\
\text { - Loss modulus } \\
\text { - Phase angle } \delta\end{array}$ & {$[50,54]$} \\
\hline Nanoindentation test & $\begin{array}{c}\text { Analysis of the surface area of } \\
\text { the composite scaffold which } \\
\text { is expected to be in contact } \\
\text { with bone }\end{array}$ & - Load-penetration curves & [54] \\
\hline Creep test & $\begin{array}{l}\text { Investigation of the improved } \\
\text { ability of the composite } \\
\text { scaffold to recover from creep } \\
\text { deformation }\end{array}$ & $\begin{array}{l}\text { - Total creep strain } \\
\text { - Creep curve }\end{array}$ & {$[34,66]$} \\
\hline Tear test & $\begin{array}{c}\text { Measure of scaffold ability to } \\
\text { withstand the effects of } \\
\text { tearing which may occur in } \\
\text { the joint }\end{array}$ & - Tear strength & {$[34]$} \\
\hline $\begin{array}{l}\text { Pull-off test of adhesion } \\
\text { Cycled bending test }\end{array}$ & $\begin{array}{l}\text { Measure of the adhesion } \\
\text { strength between composite } \\
\text { coatings and the substrate at } \\
\text { the metallization/polymer } \\
\text { interface }\end{array}$ & $\begin{array}{l}\text { - Adhesion strength } \\
\text { - Cracking and detachment } \\
\text { behaviors }\end{array}$ & {$[71]$} \\
\hline Shear strength test & $\begin{array}{l}\text { Evaluation of the response of } \\
\text { the composite scaffold to the } \\
\text { shear loading condition which } \\
\text { occurs in the joint }\end{array}$ & $\begin{array}{l}\text { - Curves of the shear strength } \\
\text { versus the immersion time }\end{array}$ & [73] \\
\hline
\end{tabular}

Typical nonlinearity of AC stress-strain behavior plays the biomechanical function of improving the support of fluid load in the tissue during physiologic compressive loading [28]. Notably, compressive loading has been previously suggested to increase solute transport as well as to promote cell mechanical stimulation. The higher the joint loading force, the greater compressive stiffness required to the cartilage substitute [84]. Together with the compressive properties, the tensile behavior of $\mathrm{AC}$ also serves to resist excess deformation and wear of the load-bearing surface during friction [85]. Thus, the responses of PVA-based hybrid hydrogel to both tensile and compressive strength are worth investigating to understand potential failures within the scaffolding system, since the compression tests define the resistance to deformation under external forces [51], while tensile stresses lead to tearing and the formation of cracks within the scaffold [86].

Together with the applied compressive/tensile forces, friction and deformation events physiologically occur on joint contact surfaces, augmenting the risk of wear and pathological problems of AC, which may lead to the onset of OA [55]. In cartilage regeneration strategies, friction may cause wear of the tissue-scaffold contact interface, leading to the displacement and failure of the engineered prosthesis [66]. Considering that, low-friction properties appear to be vital for the cartilage-mimicking scaffold to function as an ideal tissue substitute.

Less considered though not less important studies have focused on dynamic mechanical [50,54] and nanoindentation tests [54], swing and rotation analyses [56], creep and tear tests [34], toughness evaluation [68], adhesion strength and cycled bending test [71], and shear strength investigation [73] (Table 3). 


\subsection{Main Experimental Outcomes}

The enrichment of PVA hydrogel with natural or natural + synthetic materials, also considering the adopted fabrication technology, produced significant effects on the final biomechanics of the composite scaffolds (Table 4).

Table 4. Main effects of natural/synthetic additives and fabrication techniques on the mechanical properties of the composite scaffolds.

\begin{tabular}{|c|c|c|c|}
\hline Material & $\begin{array}{l}\text { Fabrication } \\
\text { Technique }\end{array}$ & Effects on Composite Scaffold Biomechanics & References \\
\hline \multirow{2}{*}{ Collagen } & Electrospinning & $\begin{array}{l}\text { - Electrospun PVA nanofiber increased the mechanical } \\
\text { stiffness of the composite PVA/hyaluronan/collagen/fibrin } \\
\text { scaffold. } \\
\text { - In the bi-layered PVA/collagen type I composites, the } \\
\text { aligned nanofibers had higher Young's modulus (stiffness), } \\
\text { ultimate strength, and strain than the random fibers. } \\
\text { - Young's modulus of seeded aligned scaffold was similar to } \\
\text { the values reported for articular cartilage ( } 0.35 \mathrm{MPa}) \text {. }\end{array}$ & {$[44,46]$} \\
\hline & Freeze-thawing & $\begin{array}{l}\text { - In the composite PVA/collagen type II/chondroitin sulfate } \\
\text { scaffold, the collagen content affected the mechanical stiffness. } \\
\text { - The addition of collagen into PVA matrix at } 1: 1 \text { ratio led to } \\
\text { an increase in elasticity modulus compared with pure PVA } \\
\text { hydrogel }(11 \pm 1.7 \text { vs. } 4.9 \pm 0.6 \mathrm{kPa}) \text {. } \\
\text { - Changing the proportion of PVA/collagen to } 1: 2 \text { caused a } \\
\text { decrease in elasticity modulus up to } 2.3 \pm 0.2 \mathrm{kPa} \text {. } \\
\text { - The highest values of elastic modulus }(12.9 \pm 1.2 \mathrm{kPa}) \text { were } \\
\text { shown with } 2: 1 \mathrm{PVA} / \text { collagen ratio. }\end{array}$ & [47] \\
\hline Hyaluronic acid & Gradual freeze-thawing & $\begin{array}{l}\text { - The stiffness gradient of PVA/hyaluronic acid hydrogels } \\
\text { (20-200 kPa) was significantly higher in comparison with } \\
\text { pure PVA hydrogel (1-24 kPa). } \\
\text { - PVA/hyaluronic acid composites exhibited a stiffness } \\
\text { gradient which varied from } 25.9 \pm 14.4 \mathrm{kPa} \text { (on the top of the } \\
\text { scaffold) to } 186.6 \pm 21.6 \mathrm{kPa} \text { (on the bottom layer). }\end{array}$ & [45] \\
\hline $\begin{array}{c}\text { Chondroitin } \\
\text { sulfate/PEGDA }\end{array}$ & Photocrosslinking & $\begin{array}{l}\text { - In the absence of the PVA sponge, PEGDA and } \\
\text { methacrylated chondroitin sulfate and hyaluronic acid } \\
\text { hydrogels exhibited Young's moduli similar to that of the PVA } \\
\text { alone, but lower degree of elastic deformation. } \\
\text { - The incorporation of photocrosslinkable hydrogels (PEGDA, } \\
\text { chondroitin sulfate/PEGDA and hyaluronic acid/PEGDA) } \\
\text { within the internal pores of the PVA sponges improved the } \\
\text { matrix rigidity (Young's modulus) and deformation without } \\
\text { breakage (toughness) of the PVA-based hybrid scaffolds. }\end{array}$ & [17] \\
\hline Chitosan & Freeze-thawing & $\begin{array}{l}\text { - In the PVA/chitosan composite, Young's modulus and } \\
\text { compressive strength increased as the PVA content increased. } \\
\text { - The hydrogel with PVA/chitosan ratio of } 6: 4 \text { demonstrated } \\
\text { the best mechanical properties. }\end{array}$ & [58] \\
\hline Chitosan/GO & $\begin{array}{l}\text { Chemical crosslinking } \\
\text { Electrospinning }\end{array}$ & $\begin{array}{l}\text { - The addition of GO improved the mechanical strength of the } \\
\text { composite scaffold. } \\
\text { - The tensile strengths of electrospun PVA/chitosan/GO } \\
\text { nanofibers were } 2.78 \mathrm{MPa} \text { and } 1.81 \mathrm{MPa} \text { for GO concentration } \\
\text { of } 0.4 \text { and } 0.6 \mathrm{wt} \% \text {, respectively. } \\
\text { - The elongations at break of composite nanofibers were } 16.79 \\
\text { and } 32.82 \% \text { with GO concentration of } 0.4 \text { and } 0.6 \mathrm{wt} \% \text {, } \\
\text { respectively. }\end{array}$ & [70] \\
\hline
\end{tabular}


Table 4. Cont.

\begin{tabular}{|c|c|c|c|}
\hline Material & $\begin{array}{l}\text { Fabrication } \\
\text { Technique }\end{array}$ & Effects on Composite Scaffold Biomechanics & References \\
\hline Alginate & Freeze-thawing & $\begin{array}{l}\text { - In the PVA/alginate composites, the mechanical properties } \\
\text { varied according to the PVA concentration into the scaffold } \\
\text { (i.e., } 10 \text { or } 20 \mathrm{wt} \%) \text {. } \\
-\mathrm{H}_{\mathrm{a}} \text { was significantly higher for } 20 \% \text { PVA constructs }(0.16 \pm \\
0.02 \mathrm{MPa} \text { ) compared to that of the } 10 \% \text { PVA scaffolds }(0.06 \pm \\
0.01 \mathrm{MPa} p=0.002) \text {, with the first kind of support showing } \\
\text { similar values to bovine articular cartilage }(0.21 \pm 0.07 \mathrm{MPa}) \text {. } \\
\text { - The } 20 \% \text { PVA scaffold was significantly stiffer than the } 10 \% \\
\text { PVA scaffold (Es } 0.14 \pm 0.02 \text { vs. } 0.04 \pm 0.01 \mathrm{MPa}) \text {, with no } \\
\text { significant difference between each scaffold type and articular } \\
\text { cartilage }(0.11 \pm 0.06 \mathrm{MPa}) \text {. } \\
\text { - E } \mathrm{E}_{\mathrm{D}} \text { was significantly higher for articular cartilage when } \\
\text { compared to that of the composite scaffolds. } \\
\text { - Under confined compression conditions, the } 20 \% \text { PVA } \\
\text { scaffolds showed no statistical differences in modulus values } \\
\text { compared to articular cartilage at all tested strain levels. }\end{array}$ & [59] \\
\hline Alginate/BG & $\begin{array}{l}\text { Ultrasonication } \\
\text { Electrophoresis deposition }\end{array}$ & $\begin{array}{l}\text { - The adhesion strength of PVA/alginate/BG coating onto the } \\
\text { substrate (stainless steel) increased significantly with PVA } \\
\text { content. } \\
\text { - Adding PVA at the proper concentration (i.e., } 20 \mathrm{~g} / \mathrm{L} \text { ) } \\
\text { ensured no visible crack formation or coating detachment } \\
\text { after } 5 \text { bending cycles. } \\
\text { - Repeated depositions of PVA/alginate/BG onto the } \\
\text { substrate produced coatings with higher thickness and } \\
\text { suitable mechanical strength. }\end{array}$ & [71] \\
\hline Alginate/PEGDA & $\begin{array}{l}\text { 3D bioprinting } \\
\text { Photopolymerization } \\
\text { Freeze-thawing }\end{array}$ & $\begin{array}{l}\text { - The PVA/alginate/PEGDA composite scaffold } \\
\text { demonstrated better anticompression capability than alginate } \\
\text { and alginate/PEGDA supports. } \\
\text { - The Young's modulus of PVA/alginate/PEGDA composite } \\
\text { scaffold ( } 6.77 \pm 0.40 \mathrm{MPa}) \text { was higher than the modulus of } \\
\text { alginate ( } 3.08 \pm 0.29 \mathrm{MPa}) \text { and alginate/PEGDA ( } 5.06 \pm 0.28 \\
\mathrm{MPa}) \text { constructs. }\end{array}$ & {$[72]$} \\
\hline \multirow{2}{*}{ Nanocellulose } & Freeze-thawing & $\begin{array}{l}\text { - The stiffness of the PVA/BC nanocomposite was higher than } \\
\text { PVA and increased with the addition of higher BC } \\
\text { concentrations. } \\
\text { - The PVA/BC possesses both improved mechanical strength } \\
\text { and increased strain-rate dependence. } \\
\text { - The PVA/BC modulus ranged from } 0.03 \text { to } 7.51 \mathrm{MPa} \text {, being } \\
\text { rather close to the elastic modulus measured for articular } \\
\text { cartilage (0.4-10 MPa). } \\
\text { - Stress relaxation tests underlined the viscoelastic behavior of } \\
\text { the nanocomposite. }\end{array}$ & {$[60]$} \\
\hline & $\begin{array}{c}\text { Ultrasonication, degas and } \\
\text { drying }\end{array}$ & $\begin{array}{l}\text { - In the PVA/NCF composites, the mechanical performance } \\
\text { was improved by the increasing NFC concentrations from } 2 \text { to } \\
6 \mathrm{wt} \% \text {. } \\
\text { - At an NFC concentration of } 6 \% \text {, the tensile strength and } \\
\text { Young's modulus of the PVA composites reached maximum } \\
\text { values, being } 2.8 \text { and } 2.4 \text { times higher than parameters } \\
\text { measured for neat PVA, respectively. } \\
\text { - When NCF content was higher than } 6 \mathrm{wt} \% \text {, the tensile } \\
\text { strength and Young's modulus showed a decrease trend, } \\
\text { ascribable to less NCF dispersion into the hydrogel. }\end{array}$ & {$[61]$} \\
\hline
\end{tabular}


Table 4. Cont.

\begin{tabular}{|c|c|c|c|}
\hline Material & $\begin{array}{l}\text { Fabrication } \\
\text { Technique }\end{array}$ & Effects on Composite Scaffold Biomechanics & References \\
\hline \multirow[t]{2}{*}{ Biological ECM } & Freeze-thawing & $\begin{array}{l}\text { - Stress-strain profiles showed stress values equal to } 0.35 \mathrm{MPa} \\
\text { for } 16 \% \text { PVA and } 0.5 \mathrm{MPa} \text { for } 25 \% \text { PVA, at } 100 \% \text { strain. } \\
\text { - } 16 \% \text { PVA did not maintain the residual strain when subjected } \\
\text { to tensile strength, revealing to be more elastic than } 25 \% \text { PVA. } \\
\text { - Comparing neat PVA and OxPVA, the stress-strain curves of } \\
\text { both polymers during the loading/unloading cycle showed to } \\
\text { overlap with no hysteresis, suggesting high resilience for } \\
\text { both samples. } \\
\text { - The elastic modulus decreased along with the degree of } \\
\text { oxidation, showing a reduction in stiffness for OxPVA. } \\
\text { - The elastic modulus did not differ between dried and } \\
\text { swelled samples. }\end{array}$ & {$[24,25]$} \\
\hline & Injectable hydrogel & $\begin{array}{l}\text { - Injectable composite scaffolds made of DBM combined with } \\
\text { different PVA concentrations }(10,20,25 \%) \text { exhibited } \\
\text { mechanical properties which depended on the PVA content. } \\
\text { - PVA alone showed significantly stronger tensile mechanical } \\
\text { characteristics than DBM/PVA. } \\
\text { - Shear modulus showed that DBM/PVA } 20 \% \text { has } \\
\text { significantly improved compressive mechanical properties in } \\
\text { comparison with other scaffolds. } \\
\text { - Young's modulus of DBM/PVA } 20 \%(5.86 \pm 0.03 \mathrm{MPa}) \text { was } \\
\text { significantly higher than other DBM/PVA groups. }\end{array}$ & {$[64]$} \\
\hline Bone/BG & Freeze-thawing & $\begin{array}{l}\text { - The addition of BG to PVA/spongy bone hydrogel led to an } \\
\text { increase in the compressive tangent modulus of the } \\
\text { composite scaffold. } \\
\text { - The shear properties of the PVA/spongy bone/BG } \\
\text { composite were mainly affected by the porous size of the } \\
\text { bone component. }\end{array}$ & [73] \\
\hline Amino acids & $\begin{array}{c}\text { In situ crosslinking } \\
\text { by citric acid }\end{array}$ & $\begin{array}{l}\text { - PVA/AA biocomposite membranes exhibited marginally } \\
\text { improved tensile strength in comparison with PVA films. } \\
\text { - Elongation-at-break was fairly decreased by AA blend. } \\
\text { - PVA/lysine biocomposites showed the maximum tensile } \\
\text { strength and good elongation characteristics, probably due to } \\
\text { the strong interaction between lysine and PVA. }\end{array}$ & [65] \\
\hline Acrylamide & Freeze-thawing & $\begin{array}{l}\text { - Creep resistance of the PVA/acrylamide gels decreased with } \\
\text { increasing acrylamide content. } \\
\text { - A strong correlation was found between elastic strain and } \\
\text { EWC and viscoelastic strain and EWC. } \\
\text { - A weak correlation was observed between viscoelastic } \\
\text { recovery and EWC and elastic recovery and EWC. } \\
\text { - Tear strength and RCOF of the PVA/acrylamide composites } \\
\text { decreased with the rise in acrylamide content. }\end{array}$ & [34] \\
\hline
\end{tabular}


Table 4. Cont

\begin{tabular}{|c|c|c|c|}
\hline Material & $\begin{array}{l}\text { Fabrication } \\
\text { Technique }\end{array}$ & Effects on Composite Scaffold Biomechanics & References \\
\hline \multirow{3}{*}{ Hydroxyapatite } & Lyophilization & $\begin{array}{l}\text { - PVA/hydroxyapatite sheets showed a ductile failure at a } \\
\text { stress of } 0.30 \mathrm{MPa} \text {. } \\
\text { - The Young's modulus calculated as the slope of the initial } \\
\text { linear portion of stress-strain curve was } 7.5 \mathrm{MPa} \text {. }\end{array}$ & [49] \\
\hline & Freeze-thawing & $\begin{array}{l}\text { - The compressive strength, compressive modulus, storage } \\
\text { modulus, and loss modulus of the composite scaffold first } \\
\text { increased and then decreased with the rise in hydroxyapatite } \\
\text { content in the PVA matrix. } \\
\text { - The compressive strength, storage modulus, and loss } \\
\text { modulus increased with the rise in PVA concentration in the } \\
\text { composite scaffold. } \\
\text { - The compressive strength, compressive modulus, and elastic } \\
\text { and loss modulus increased with the number of } \\
\text { freeze-thawing cycles, with the increase rate reducing at } \\
\text { higher freeze-thaw cycle times. } \\
\text { - The tensile test revealed an increase in the tensile Young's } \\
\text { modulus (up to } 460 \pm 20 \text { kPa) with the addition of } \\
\text { hydroxyapatite in comparison with neat PVA ( } 250 \pm 50 \mathrm{kPa}) \text {. } \\
\text { - Nanoindentation tests confirmed the contribution of the } \\
\text { hydroxyapatite to increase the hardness of the composite, } \\
\text { since a decrease in the work of adhesion to the indenter tip } \\
\text { was observed. } \\
\text { - Scaffolds with lower concentrations of hydroxyapatite were } \\
\text { found to have the lowest friction coefficient (0.067 } \pm 0.049) \\
\text { together with a high resistance ( } 721 \pm 25 \mathrm{kPa} \text { ). } \\
\text { - Evaluating the torsional friction behavior of the composites } \\
\text { against CoCrMo femoral head, the average friction torques } \\
\text { were } 0.74,3.69 \text {, and } 9.89 \text { Nmm during the torsional friction } \\
\text { with } 10,30 \text {, and } 50 \text { N loads, respectively. } \\
\text { - Fluid loss of the composite hydrogel increased as the friction } \\
\text { time, load, and torsional angle increased, leading to the } \\
\text { decrease in fluid load support and the increase in friction } \\
\text { coefficient. } \\
\text { - PVA/hydroxyapatite composite hydrogel crosslinked on } \\
\text { UHMWPE acetabulum showed negligibly small swing and } \\
\text { torsion friction coefficients and largest sliding friction } \\
\text { coefficient. }\end{array}$ & {$[50-56]$} \\
\hline & Directional freeze-thawing & $\begin{array}{l}\text { - The bi-layered gradient PVA/hydroxyapatite hydrogel } \\
\text { presented gradient mechanical strength with tensile modulus } \\
\text { ranging from } 0.18 \text { to } 0.27 \mathrm{MPa} \text {. } \\
\text { - The gradient compressive modulus ranged from } 0.33 \text { to } \\
0.51 \mathrm{MPa} \text {. }\end{array}$ & [57] \\
\hline
\end{tabular}


Table 4. Cont

\begin{tabular}{|c|c|c|c|}
\hline Material & $\begin{array}{l}\text { Fabrication } \\
\text { Technique }\end{array}$ & Effects on Composite Scaffold Biomechanics & References \\
\hline Hydroxyapatite/PAA & $\begin{array}{c}\text { Freeze-thawing } \\
\text { Annealing treatment }\end{array}$ & $\begin{array}{l}\text { - The creep deformation of the composite scaffold decreased } \\
\text { with the rise in PVA concentration. } \\
\text { - The creep deformation of the hydrogel increased first and } \\
\text { then decreased with the rise in PAA content. } \\
\text { - Hydroxyapatite had a minor effect on the creep properties. } \\
\text { - The stress relaxation rate decreased with the decrease in PVA } \\
\text { content. At the same time, it first decreased and then } \\
\text { increased with the rise in PAA. } \\
\text { - Hydroxyapatite seemed to have the weakest effect on stress } \\
\text { relaxation properties. } \\
\text { - The stress relaxation rate decreased with increasing } \\
\text { annealing temperature. } \\
\text { - According to the compressive stress-strain curve, the } \\
\text { composite hydrogel had a typical viscoelastic behavior, } \\
\text { resembling natural AC. } \\
\text { - The elastic modulus of the composite hydrogel increased } \\
\text { with the annealing temperature. } \\
\text { - The elastic modulus of the composite hydrogel decreased } \\
\text { first and then increased with increasing freeze-thawing cycles. } \\
\text { - Increasing the content of hydroxyapatite and PAA, the elastic } \\
\text { modulus showed a trend of increasing first and then } \\
\text { decreasing. } \\
\text { - The friction coefficient of the composite hydrogels was } \\
\text { relatively low and shown to increase with the contact load. } \\
\text { - The friction coefficient of the composite hydrogels increased } \\
\text { and then decreased with the increase in sliding rate. }\end{array}$ & [66] \\
\hline Hydroxyapatite/PLGA & Freeze-thawing & $\begin{array}{l}\text { - The double-layer PVA/hydroxyapatite hydrogel coated with } \\
\text { PVA/hydroxyapatite/PLGA scaffold demonstrated to be a } \\
\text { viscoelastic material. } \\
\text { - The compressive stress and tensile stress of } \\
\text { PVA/hydroxyapatite alone was higher than that of the } \\
\text { PVA/hydroxyapatite/PLGA scaffold. } \\
\text { - The ultimate compressive stress and ultimate tensile stress of } \\
\text { the PVA/hydroxyapatite/PLGA scaffold-modified } \\
\text { PVA/hydroxyapatite hydrogel was lower than that of the } \\
\text { HA/PVA hydrogel and higher than that of the } \\
\text { PVA/hydroxyapatite/PLGA hydrogel. } \\
\text { - The compressive/tensile stress and the ultimate } \\
\text { compressive/tensile stress increased along with the increase } \\
\text { in the composition ratio of the PVA/hydroxyapatite hydrogel. }\end{array}$ & \\
\hline
\end{tabular}


Table 4. Cont.

\begin{tabular}{|c|c|c|c|}
\hline Material & $\begin{array}{l}\text { Fabrication } \\
\text { Technique }\end{array}$ & Effects on Composite Scaffold Biomechanics & References \\
\hline Hydroxyapatite/PAA & $\begin{array}{c}\text { Freeze-thawing } \\
\text { Annealing treatment }\end{array}$ & $\begin{array}{l}\text { - The creep deformation of the composite scaffold decreased } \\
\text { with the rise in PVA concentration. } \\
\text { - The creep deformation of the hydrogel increased first and } \\
\text { then decreased with the rise in PAA content. } \\
\text { - Hydroxyapatite had the minor effect on the creep properties. } \\
\text { - The stress relaxation rate decreased with the decrease in PVA } \\
\text { content. At the same time, it first decreased and then } \\
\text { increased with the rise in PAA. } \\
\text { - Hydroxyapatite seemed to have the weakest effect on stress } \\
\text { relaxation properties. } \\
\text { - The stress relaxation rate decreased with the increasing of } \\
\text { annealing temperature. } \\
\text { - According to the compressive stress-strain curve, the } \\
\text { composite hydrogel had a typical viscoelastic behavior, } \\
\text { resembling natural AC. } \\
\text { - The elastic modulus of the composite hydrogel increased } \\
\text { with the annealing temperature. } \\
\text { - The elastic modulus of the composite hydrogel decreased } \\
\text { first and then increased with the increasing of freeze-thawing } \\
\text { cycles. } \\
\text { - Increasing the content of hydroxyapatite and PAA, the elastic } \\
\text { modulus showed a trend of increasing first and then } \\
\text { decreasing. } \\
\text { - The friction coefficient of the composite hydrogels was } \\
\text { relatively low and showed to increase with the contact load. } \\
\text { - The friction coefficient of the composite hydrogels increased } \\
\text { and then decreased with the increase in sliding rate. }\end{array}$ & [66] \\
\hline Hydroxyapatite/PLGA & Freeze-thawing & $\begin{array}{l}\text { - The double-layer PVA/hydroxyapatite hydrogel coated with } \\
\text { PVA/hydroxyapatite/PLGA scaffold was demonstrated to be } \\
\text { a viscoelastic material. } \\
\text { - The compressive stress and tensile stress of } \\
\text { PVA/hydroxyapatite alone was higher than that of the } \\
\text { PVA/hydroxyapatite/PLGA scaffold. } \\
\text { - The ultimate compressive stress and ultimate tensile stress of } \\
\text { the PVA/hydroxyapatite/PLGA scaffold-modified } \\
\text { PVA/hydroxyapatite hydrogel was lower than that of the } \\
\text { HA/PVA hydrogel and higher than that of the } \\
\text { PVA/hydroxyapatite/PLGA hydrogel. } \\
\text { - The compressive/tensile stress and the ultimate } \\
\text { compressive/tensile stress increased along with the increase } \\
\text { in the composition ratio of the PVA/hydroxyapatite hydrogel. }\end{array}$ & [67] \\
\hline Hydroxyapatite/HACC & $\begin{array}{c}\text { Freeze-thawing } \\
\text { Immersion in } \\
\mathrm{Na}_{3} \mathrm{Cit} \\
\text { for dual } \\
\text { physical crosslinking }\end{array}$ & $\begin{array}{l}\text { - The addition of hydroxyapatite nanoparticles led to a slight } \\
\text { decrease in the ultimate tensile stress and elongation and a } \\
\text { slight increase in the compressive stress of the composite } \\
\text { scaffold. } \\
\text { - After crosslinking with } \mathrm{Na}_{3} \mathrm{Cit} \text {, the } \\
\text { PVA/hydroxyapatite/HACC-Cit scaffold exhibited improved } \\
\text { load-bearing and self-recovery ability. } \\
\text { - The ultimate tensile stress and compressive stress of } \\
\text { composites after dual crosslinking were nearly } 10 \text { and } 12 \\
\text { times higher, respectively, in comparison with composites } \\
\text { which were not treated with } \mathrm{Na}_{3} \text { Cit. } \\
\text { - The fracture toughness and compressive Young's modulus of } \\
\text { the composite significantly increased after dual crosslinking. }\end{array}$ & [68] \\
\hline
\end{tabular}


Table 4. Cont.

\begin{tabular}{|c|c|c|c|}
\hline Material & $\begin{array}{l}\text { Fabrication } \\
\text { Technique }\end{array}$ & Effects on Composite Scaffold Biomechanics & References \\
\hline Hydroxyapatite/GO & $\begin{array}{l}\text { Extrusion 3D printing } \\
\text { Freeze-thawing }\end{array}$ & $\begin{array}{l}\text { - Higher concentration of PVA ( } 25 \mathrm{wt} \%) \text { better matched the } \\
\text { mechanical properties of AC in terms of compressive strength } \\
(0.93 \mathrm{MPa}) \text { and compressive modulus }(0.96 \mathrm{MPa}) \text {. } \\
\text { - The addition of hydroxyapatite and GO significantly } \\
\text { improved the printability and printing accuracy of PVA } \\
\text { solution, ensuring the structure integration and better } \\
\text { mechanical properties. } \\
\text { - The 3D-printed construct appeared to be difficult to be } \\
\text { destroyed under cyclic compression, suggesting excellent } \\
\text { antifatigue ability from the perspective of being used during } \\
\text { joint motion (i.e., jumping and running). } \\
\text { - 3D-printed PVA/hydroxyapatite/GO samples displayed a } \\
\text { time-dependent friction response which was similar to that of } \\
\text { AC, reaching a final value as low as } 0.0698 . \\
\text { - No furrows were detected on the surface morphologies for } \\
\text { the friction area of the composite hydrogel, suggesting good } \\
\text { wear resistance of the structure. }\end{array}$ & [69] \\
\hline
\end{tabular}

Abbreviations: AA, amino acids; AC, articular cartilage; BC, bacterial cellulose; BG, bioactive glass; CoCrMo, cobalt-chromiummolybdenum alloy; DBM, demineralized bone matrix; $\mathrm{E}_{\mathrm{D}}$, dynamic modulus; $\mathrm{E}_{\mathrm{S}}$, elastic modulus; EWC, equilibrium water content; GO, graphene oxide; $\mathrm{H}_{\mathrm{a}}$, aggregate modulus; $\mathrm{HACC}$, 2-hydroxypropyltrimethyl ammonium chloride chitosan; $\mathrm{Na}{ }_{3} \mathrm{Cit}$, sodium citrate; $\mathrm{NCF}$, nanocellulose fibrils; OxPVA, oxidized PVA; PAA, polyacrylic acid; PEGDA, poly(ethylene glycol) diacrylate; PLGA, poly(lactic-co-glycolic) acid; PVA, polyvinyl alcohol; RCOF, relative coefficient of friction; UHMWPE, ultrahigh molecular weight polyethylene.

\subsubsection{Collagen}

The combination between PVA and collagen resulted in endowing the composite scaffold with mechanical properties which can satisfy the requirements of natural cartilage.

Lan and co-authors [47] demonstrated that the mechanical stiffness of the composite PVA/collagen type II/chondroitin sulfate scaffold was modulated by the collagen content. Elasticity modulus of the composite scaffold was increased in comparison with the pure PVA hydrogel when collagen was added in the same or in minor quantity to PVA. On the other hand, the elasticity modulus decreased along with the increase in the collagen content. Interestingly, PVA/collagen I scaffold with aligned fibers exhibited significantly higher Young's modulus and ultimate tensile strength than composites formed by random collagen fibers. Remarkably, for both aligned and random scaffolds, the biomechanical parameters were ameliorated after chondrocyte seeding and growth on the scaffold, with the Young's modulus of seeded aligned scaffold being similar to the values reported for AC [46].

Finally, as a direct effect of the fabrication technique, electrospun PVA nanofiber embedded in a hyaluronate/collagen type I/fibrin composite hydrogel led to a detectable increase in the mechanical stiffness of the resulting hybrid scaffold [44].

\subsubsection{Cartilage-Specific Components \pm Synthetic Additives}

Considering PVA/hyaluronic acid hydrogels fabricated by gradual freeze-thawing method, they were found to exhibit a wide range stiffness gradient $(20-200 \mathrm{kPa})$, which were significantly improved in comparison with pure PVA hydrogel $(1-24 \mathrm{kPa})$. This could be ascribed to the formation of semi-IPN of the hyaluronic acid chains in the PVA hydrogel. The resulting stiffness range of the composite scaffold appeared to adequately cover the stiffness range of most human tissues, including AC [45].

Interestingly, photopolymerizable cartilage-specific bioactive components, such as hyaluronic acid and chondroitin sulfate, proved to be responsible for the mechanical reinforcement of the PVA-based scaffolds. In particular, when photocrosslinked hyaluronic acid/PEGDA and chondroitin sulfate/PEGDA hydrogels were incorporated within the pores of PVA sponges, the composite scaffolds exhibited improved rigidity and deformation capacity with no breakage. This effect can be ascribable to (a) the increase in the 
crosslinking density via IPN formation and (b) the presence of incompressible moieties (PEGDA, methacrylated hyaluronic acid/chondroitin sulfate) within the PVA pores, which better resemble AC biophysical characteristics and functions [17].

\subsubsection{Hydroxyapatite \pm Synthetic Additives}

The mechanical performance of PVA-based hybrid hydrogels combined with hydroxyapatite was extensively investigated through a number of mechanical tests. These studies conveyed that the biomechanical characteristics of PVA/hydroxyapatite scaffolds are ameliorated in comparison with the pure hydrogel, being nonetheless strictly influenced by the hydroxyapatite and PVA concentrations as well as the number of freeze-thawing cycles $[49,50]$. Hydroxyapatite addition at lower concentrations was found to cause a significant increase in the storage modulus, loss modulus [50,54], compressive strength [51-53], and compressive modulus [52,54] of composite hydrogels. However, the parameters registered a decreasing trend as the hydroxyapatite counterpart was augmented over a certain quantity. The decrease in mechanical performance when the hydroxyapatite particle content is excessively increased has been reported by several authors and can be attributed to the agglomeration of particles in the PVA hydrogel when they exceed a certain concentration. In accordance with many findings, excessive hydroxyapatite particles do not seem to be well distributed and dispersed in the PVA matrix, producing agglomeration and ultimately resulting in deterioration of the composite mechanical properties [50-54].

The dependence of compressive strength and storage/loss modulus on freeze-thawing cycles also showed different trends, first increasing with the number of thermal cycles, and then with a reduction in the increase rate at higher numbers of freeze-thaw cycles. This can be ascribed to the fact that, over a certain number of cycles, saturation of the interand intrapolymer hydrogen bonding responsible for the compact material network occurs, causing less compressive strength of the material $[50,51]$.

Furthermore, both the storage and loss modulus were found to increase with the rise in PVA concentration due to the increase in crosslink junctions and the formation of a more compact network structure in the composite scaffold [50].

Sample hydration was shown to affect the stress-strain behavior of PVA/hydroxyapatite composites, changing from nonlinear, in a hydrated state, to linear behavior in a dried state. The first condition was consistent with AC behavior. Scaffolds with lower concentrations of hydroxyapatite were found to have the lowest friction coefficient $(0.067 \pm 0.049)$ together with a high resistance $(721 \pm 25 \mathrm{kPa})$; these are important properties for materials that will be used as articular replacements [52].

Besides PVA/hydroxyapatite hydrogels fabricated by the most common freeze-thawing method, gradient layer-structured composites obtained by DFT and electrophoresis process were demonstrated to retain the mechanical properties needed for the simultaneous repair of cartilage and subchondral bone. Indeed, these bi-layered hybrid scaffolds exhibited gradient tensile modulus ranging from 0.18 to $0.27 \mathrm{MPa}$ and gradient compressive modulus ranging from 0.33 to $0.51 \mathrm{MPa}$ [57].

Another bi-layered composite made of PVA/hydroxyapatite hydrogel coated with PVA/hydroxyapatite/PLGA scaffold was mechanically characterized as a novel viscoelastic material which can well resemble native AC. The core section of the hydrogel (PVA/ hydroxyapatite layer) was mainly responsible for the mechanical performance, with the compressive/tensile stress increasing along with the increase in the specific composition ratio. Thus, the biomechanical properties of this new composite can be controlled to meet the required physical needs by adjusting the ratio of each layer during the fabrication process [67].

Notably, Chen and collaborators [66] asserted that hydroxyapatite had a minor effect on the creep and stress relaxation properties of PVA/hydroxyapatite/PAA composites in comparison with other variables such as PVA and PAA concentrations, number of freeze-thawing cycles, and annealing temperature. A greater influence was exerted by hydroxyapatite on the elastic modulus of the composite scaffold, which was also affected 
by the PAA content, the number of freeze-thawing cycles and the annealing temperature. The compressive stress-strain curve revealed that the PVA/hydroxyapatite/PAA hydrogel had a typical cartilage-mimicking viscoelastic behavior [66].

As a result of the fabrication technique, the use of dual physical crosslinking by freezethawing and subsequent immersion in $\mathrm{Na}_{3} \mathrm{Cit}$ allowed reinforcement of the mechanical performance of the PVA/hydroxyapatite/HACC-Cit composite in terms of (a) increased load-bearing and self-recovery abilities, (b) higher ultimate tensile stress and compressive stress, and (c) augmented fracture toughness and compressive modulus [68].

Finally, PVA-based scaffold fabrication by 3D printing resulted in being significantly more accurate thanks to the addition of hydroxyapatite and GO. Due to their compressive strength and modulus being improved mainly by the increase in PVA concentration, the PVA/hydroxyapatite/GO composites showed high strength under cycling compression as well as friction response and wear resistance similar to those of AC [69].

Overall, the general mechanical behavior of the composite scaffolds based on PVA and hydroxyapatite combination indicated that they could be efficiently used as AC replacements.

\subsubsection{Chitosan and Alginate \pm Synthetic Additives}

Biohybrid hydrogels prepared with different PVA/chitosan ratios were demonstrated to have mechanical properties which varied according to the concentration of the synthetic or natural components. In particular, the Young's modulus and compressive strength increased with the rise in PVA content. However, if the compressive/tensile strength of the hydrogel is too high, the growth of new tissue surrounding the grafted scaffold can be compromised by shear stresses created by the hydrogel. Therefore, the best PVA/chitosan ratio needs to be chosen while taking other properties into consideration, rather than only the mechanical performance [58].

Additionally, PVA/chitosan/GO composite nanofibers obtained by electrospinning technique were found to have high tensile strength and good elongation-at-break. Starting from the well-known mechanical properties of GO, the electrospinning process with its electrostatic forces allowed increasing the interactions among GO and PVA/chitosan chains, resulting in the fabrication of high-strength nanofibers [70].

Stress relaxation tests on PVA/alginate hybrid scaffolds prepared with 10 and $20 \mathrm{wt} \%$ PVA concentrations highlighted that the elastic modulus $\left(\mathrm{E}_{\mathrm{s}}\right)$ and aggregate modulus $\left(\mathrm{H}_{\mathrm{a}}\right)$ significantly increased with the rise in PVA content. Notably, $E_{s}$ was similar to that of AC for both polymer concentrations, while $\mathrm{H}_{\mathrm{a}}$ and dynamic modulus $\left(\mathrm{E}_{\mathrm{D}}\right)$ were similar to that of cartilage only at $20 \%$ PVA [59].

The combination of PVA with alginate/BG allowed for the production of reinforced coatings which were deposited onto stainless steel substrate with repeated stratifications to increase coating thickness and mechanical strength. Remarkably, the adhesion strength of the composite sheet was significantly augmented with the presence of PVA, confirming the polymer's important role on the packing density of the coatings and on the connection between the coating and the substrate [71]. In line with these findings, PVA/alginate/PEGDA composite scaffold exhibited better anticompression capability than alginate and alginate/PEGDA supports. Produced by 3D printing technology, this hybrid scaffold showed improved surface topography, mechanical strength, and structure stability on the basis of PVA ratio and number of freeze-thawing cycles [72].

\subsubsection{Nanocellulose}

Cellulose nanofibers were found to confer strong reinforcement towards tensile stress and a wide range of compressive mechanical properties of the PVA-based scaffold. Hybrid supports combining the PVA matrix with BC nanofibers showed compressive elastic modulus values similar to those reported for native $\mathrm{AC}$. The nanocomposites demonstrated improved mechanical strength, viscoelasticity, and strain-rate dependence as compared to PVA alone. As already observed for other hybrid scaffolds, the stiffness of PVA/BC 
composite under compression significantly increased as the number of freeze-thawing cycles augmented. Displaying a cartilage-mimicking viscoelastic behavior when subjected to stress relaxation tests, the PVA/BC nanocomposite turned out to be a promising replacement material for localized AC injuries [60].

Similar to the effects produced by hydroxyapatite addition, the mechanical properties of PVA/NCF composites increased and then decreased depending on NCF content. In particular, the tensile strength and Young's modulus of PVA/NFC hybrid scaffolds were demonstrated to strongly increase with the rise in NCF content from 2 to $6 \mathrm{wt} \%$. Over $6 \mathrm{wt} \%$ NCF concentration, the mechanical parameters registered a declining trend, probably due to less homogeneous NCF dispersion, causing local concentrations of stress and inducing premature tensile failure [61].

\subsubsection{Biological ECM \pm Synthetic Additives}

The mechanical strength of the composites combining PVA with ECM from human AC or Wharton's jelly was strictly dependent on the synthetic hydrogel, since the biological matrices were obtained as nonstructured homogenates and lyophilized bioactive sheets crosslinked on the scaffold surface. Lower concentrations of PVA solution led, after physical freeze-thawing, to the production of more elastic hydrogels [24]. The chemical post-modification of the polymer by partial oxidation of 1 or $2 \%$ of the hydroxyl groups to carbonyl groups produced a decrease in hydrogel stiffness which was proportional to the degree of oxidation. In any case, the polymer preserved an elastic modulus which fell into the value range required for $\mathrm{AC}$ replacement [25].

Besides PVA/ECM 3D scaffolds, injectable PVA/DBM composites were mechanically investigated to be used for cartilage repair, exhibiting less strong tensile mechanical properties than pure PVA. This is probably due to the fact that DBM led to a reduction in polymeric chain interactions, also causing some disintegration in the hydrogel configuration, which may produce a decrease in tensile strength. Testing different PVA concentrations into the injectable scaffold, the highest Young's modulus in the composite was registered with $20 \%$ polymer concentration. Despite showing lower viscoelastic and elastic behavior than pure PVA scaffolds, $20 \%$ PVA/DBM composites maintained favorable durability in terms of strength to resemble the native cartilage tissue [64].

Considering that the pure PVA possesses poor interaction function with the base bone, PVA/spongy bone composites were enriched with BG to promote mineralization and establish a bioactive connection at the bone interface. In these hybrid scaffolds, the shear strength resulted in an increase along with the pore size of the spongy bone, demonstrating that the larger porous size of the bone contributes majorly to the shear properties and provides a stronger interface with more physical interlocks between the hydrogel and bone itself [73].

\subsubsection{Amino Acids and Acrylamide}

Blending AA to PVA marginally increased the tensile strength of PVA/AA biocomposite membranes. Elongation-at-break was decreased by AA blending since the AA residues form additional hydrogen bonds with PVA polymer chains, which function as reinforcing units but prevent chain movement. Overall, electrostatic interactions among PVA polymeric chains and AA confer good mechanical stability to the biocomposites, with the maximum tensile strength reached with the addition of lysine, which likely formed stronger interactions with PVA [65].

In an effort to ameliorate the creep resistance of PVA hydrogels, acrylamide was polymerized within the polymer pores. This allowed avoiding high-temperature annealing, which can lead to pore collapse as well as reduce water content and surface lubricity. The resulting PVA/acrylamide composites effectively displayed increased porosity and equilibrium water content, whereas the coefficient of friction, tear strength, and creep resistance decreased with the raise of acrylamide content [34]. 


\section{Biocompatibility of Hybrid Scaffolds for Cartilage TE}

After the characterization of the mechanical properties, in vitro and in vivo studies are mandatory to assess the biosafety and cell/tissue interactive potential of biomimetic scaffolds from the perspective of possible clinical application. Biocompatibility assessment of implantable materials include cytotoxicity tests, cell seeding experiments, and preclinical studies through the in vivo implantation into animal models.

While in vitro tests are based on simplified models in comparison with the complex physiological environment, they valuably contribute to providing insights into potential in vivo tissue/cellular responses before preclinical and clinical studies [87].

In vitro cell cultures using tissue-specific or undifferentiated stem cells are regarded as the simplest method to simulate tissue-biomaterial interactions and collect morphological, biochemical, and molecular evidence on biomaterial biocompatibility and matrix synthesis at the tissue-biomaterial interface. Common experimental tests focus on defining scaffold effects on cell viability, morphology, adhesion, proliferation, differentiation, and synthetic activity [88].

On the other hand, animal studies provide important biomaterial knowledge on both the eventual inflammatory response elicited by scaffold grafting and the regenerative potential of the biomaterial in case of orthotopic implantation into models of tissue damage. Preclinical evaluation of biomedical scaffolds may act as a bridge between in vitro studies and clinical trials [89].

\subsection{In Vitro Cytotoxicity and Cell Seeding Studies}

The biocompatibility of PVA-based hybrid scaffolds as cartilage TE was mainly assessed in vitro by cell culture studies. The tested cell populations include bone marrow mesenchymal stem cells (MSCs) of pig [44], rabbit [58,64], and human [45] origin, primary chondrocytes from porcine [46], murine [47], rabbit [17,67], and human [24,25] cartilage, as well as mouse embryo osteoblast precursor (MC3T3-E1) cells [57,68,72], ATDC5 murine chondrogenic cell line [59,70], and MG-63 osteoblast-like cell line [65].

Hyaluronate/collagen/fibrin composite scaffold containing PVA nanofibers enriched with liposomes, bFGF, and insulin were demonstrated to promote adhesion and improve the viability of seeded MSCs due to the growth factor release activity of the support [44]. The scaffold was revealed to function as a delivery system which vehicles bioactive factors to the damage site. Confirming cell sensitivity to scaffold mechanical properties, stiffness gradient PVA/hyaluronic acid hydrogels showed to possess tunable cell-instructive capacities related to different substrate stiffness within the scaffold. Once seeded on this composite, MSCs not only found a biocompatible support where they could adhere and proliferate but also received stimuli from the scaffold, inducing differentiation into various specific cell types. According to scaffold stiffness, the softer hydrogel layers allowed for better neurogenic differentiation, while the stiffer hydrogel sections stimulated higher osteogenic differentiation. Myogenic and chondrogenic differentiation occurred when MSCs were seeded on the hydrogel sections with moderate stiffness [45]. PVA/chitosan composites also demonstrated no cytotoxicity on MSCs as well as the ability to promote cell proliferation. When MSCs were cultured on PVA/chitosan supports in inductive medium, their chondrogenic potential was enhanced, and differentiation into chondrocytes occurred [58]. Finally, PVA/DBM composites turned out to promote MSC adhesion and growth, aside from inducing their specific differentiation into chondrocytes expressing SOX9 and collagen type II at both mRNA and protein levels [64].

Primary chondrocytes culture experiment corroborated the data about the cytocompatibility of PVA-based hybrid constructs. PVA/collagen type I electrospun nanofibers were found to trigger chondrocyte proliferation as well as their secretion of glycosaminoglycans (GAGs) and collagen type II [46]. In line with these results, PVA/collagen type II hydrogels obtained by physical crosslinking were also demonstrated to sustain chondrocyte adhesion and proliferation [47]. 
Intriguingly, rabbit chondrocytes showed different growth on double-layer PVA/ hydroxyapatite hydrogel coated with PVA/hydroxyapatite/PLGA scaffold. In particular, the peripheral PLGA/hydroxyapatite/PVA component resulted in better sustained adhesion and proliferation of cartilage cells, which were also found to produce collagen type II-positive granules in the cytoplasm and cell membrane [67].

When chondrocytes were photo-encapsulated in PEGDA/chitosan and PEGDA/ hyaluronic acid and loaded into macroporous PVA hybrid scaffolds, they were shown to upregulate different chondrogenic genes (i.e., collagen type II, aggrecan, hyaluronan synthase, proteoglycan). Furthermore, the cell-secreted ECM led to significant mechanical reinforcement of PVA/PEGDA/chitosan and PVA/PEGDA/hyaluronic acid composites by 83.30 and $73.76 \%$, respectively, in comparison with the unseeded supports [17]. Finally, in PVA/ECM hybrid scaffolds seeded with human chondrocytes, decellularized AC and Wharton's jelly sheets crosslinked with PVA hydrogels demonstrated conferment of cell adhesive properties to the polymer (Figure 4), which was not able to sustain cell growth alone $[24,25]$.
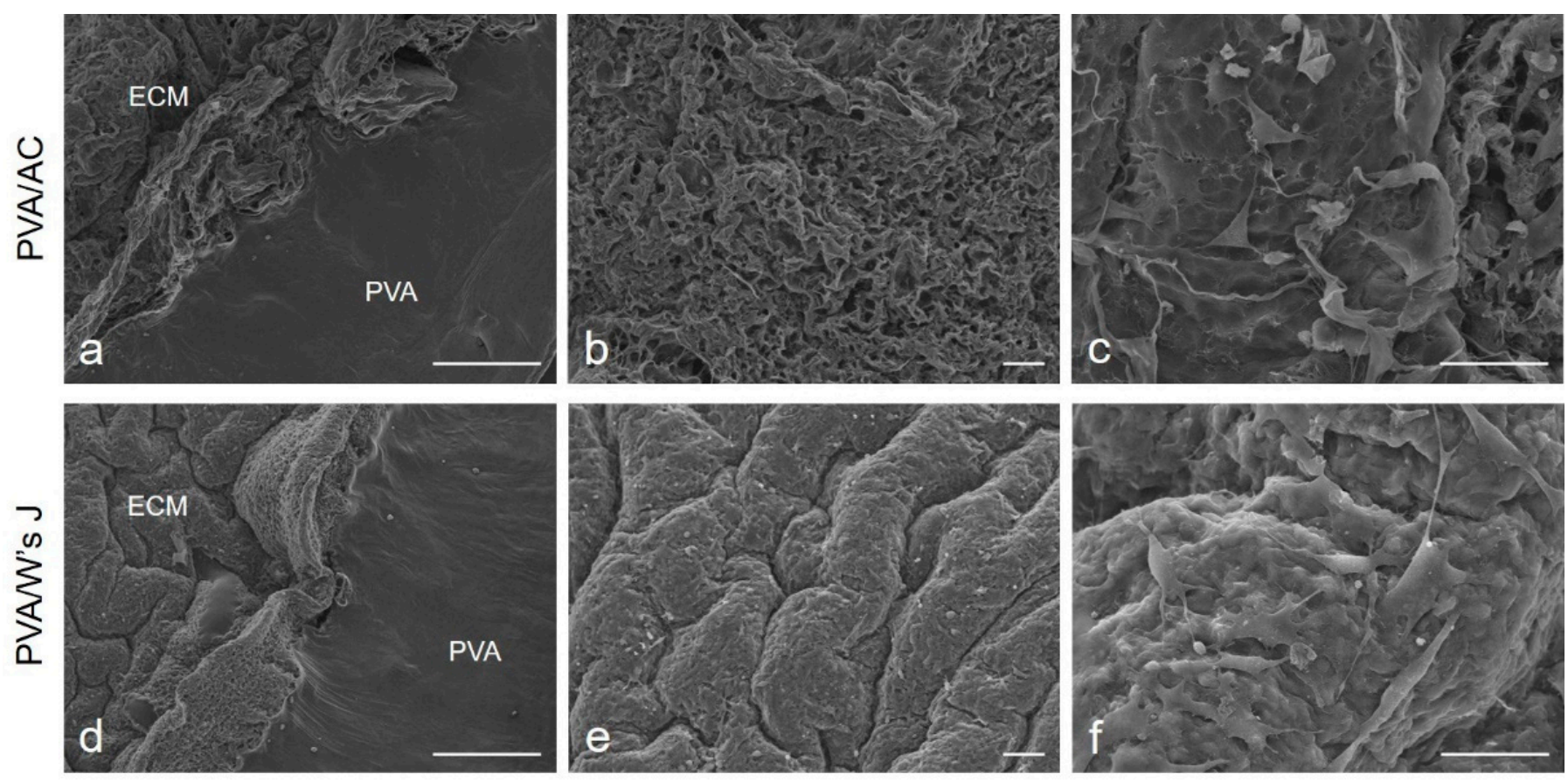

Figure 4. Scanning electron microscope micrographs of bi-layered composite scaffolds made of PVA and AC (a-c) or Wharton's jelly (W's J) (d-f) ECM, seeded with human chondrocytes for 7 days. Scale bar: (a,d) $500 \mu \mathrm{m}$; (b,e) $100 \mu \mathrm{m}$; (c,f) $50 \mu \mathrm{m}$.

Considering cell line cultures on PVA-based hybrid scaffolds, bi-layered PVA/ hydroxyapatite hydrogels exhibited different cell adhesion properties at the two regions of the composite. By virtue of their fabrication method, these supports contain hydroxyapatite nanoparticles in only half of the scaffold. As a result of this specific scaffold topography, few scattered MC3T3-E1 preosteoblasts in a round shape were found to adhere where the gel was nearly pure PVA. Conversely, where the gel was a composite, lots of living cells adhered to the surface and started to proliferate, as demonstrated by their spindle or polygonal shape [57]. Excellent MC3T3-E1 cell viability, attachment, and growth were also observed on the hybrid hydrogels formed by PVA/hydroxyapatite/HACC-Cit [68] and PVA/alginate/PEGDA [72].

Cytocompatibility studies carried out with the chondrogenic cell line ATDC5 highlighted the ability of PVA/alginate hydrogels [59] and PVA/chitosan/GO nanofibers [70] to sustain cell adhesion and proliferation. In particular, ATDC 5 cells injected at three evenly spaces along the side of the PVA/alginate composite were then found as viable elements 
within and on top of the scaffold, suggesting their possible migration from the points of injection through the scaffold's open pores [59].

Cell adhesion results obtained on PVA/AA biocomposite films revealed that the addition of AA enhanced cell-substrate binding by modulating cellular activity of the polymer. Amongst the three types of composites, PVA/lysine film gave the best outcome in terms of MG-63 cell adhesion, probably due to the presence of a higher number of positive charges on the scaffold surface [65].

\subsection{In Vivo Implant}

Regarding preclinical studies, only four of the reviewed papers reported the in vivo implant of PVA-based biohybrid cartilage substitutes, which represents an important gap in knowledge.

Scaffold biocompatibility assessment by subcutaneous implantation tests in BALB/c mice was reported for PVA/PEGDA/chitosan and PVA/PEGDA/hyaluronic acid composites. Not eliciting any inflammatory responses, cell-laden hybrid scaffolds showed lacunae formation surrounding round chondrocytes and promoted ectopic cartilage-like ECM deposition, confirmed by the detection of collagen type II-positive cells.

Cell-free hyaluronate/collagen/fibrin composites containing PVA nanofibers enriched with liposomes, bFGF, and insulin were in situ implanted into osteochondral defects of minipigs and left for 12 weeks, revealing good osteochondral regeneration potential. Besides stimulating the neoformation of hyaline cartilage and/or fibrocartilage compared with untreated defects filled with fibrous tissue, the composite scaffolds enhanced migration of the cells into the damaged site and their differentiation into chondrocytes [44].

A similar model of osteochondral defects in the articular cartilage of rabbits was created to assess in vivo regenerative potential of PVA/chitosan scaffolds during 12 weeks with implants. Aside from the untreated defect control group, a comparison was made between cell-free or MSC-laden composites, highlighting that PVA/chitosan supports seeded with MSCs achieved the best cartilage healing [58].

The injectable hybrid scaffold made of PVA/DBM seeded with MSCs was used to repair osteochondral defect of rabbit femur in a period of 24 weeks. Overall repair assessment evaluated by International Cartilage Repair Society (ICRS) scores showed that there was no significant difference between the composite scaffold graft and the normal cartilage. Moreover, ICRS visual histological assessment scale confirmed the hyalin-like morphology of the repaired cartilage, where seeded MSCs seemed to be stimulated by the composite scaffold to differentiate and produce their own ECM, expressing proteoglycans and collagen II [64].

\section{Overall Considerations and Conclusions}

Cartilage damage still represents a challenge for modern medicine, with the current therapies being still far from the ideal restoration of AC function. Recent advances in TE strategies have led to the design and fabrication of biocompatible substitutes that aim to repair, maintain, or improve tissue function for therapeutic purposes [18]. To enhance cartilage regeneration, an intriguing opportunity is represented by the use of cell-free or cell-laden biomimetic scaffolds, assuring for the mechanical support and cues which can highly resemble the multiphasic nature of AC. Moreover, endowing scaffolds with specific bioactive properties will aid in efficiently promoting functional repair in situ by stimulating the proliferation and terminal commitment of local progenitor cells or by recruiting stem cells from a nonlocal niche (i.e., bone marrow). Being highly biocompatible and cost-effective, this approach has great potential for translation in the clinical practice; nonetheless, the optimal scaffold for AC replacement seems not to have been designed yet [3].

In this scenario, PVA hydrogel and its composites have gained increasing attention as novel artificial cartilage replacements [66]. Reviewing the literature, hybrid scaffolds derived by the combination of PVA with natural or natural + synthetic materials are 
demonstrated to possess excellent mechanical properties that match the complex mechani$\mathrm{cal} /$ tribological behavior of cartilage tissue. Specific investigations have mainly considered the mechanical performance of the composites under compressive and tensile loading, closely resembling the physiological forces that $\mathrm{AC}$ has to face in vivo. Most of these studies highlighted that the stiffness and compression strength of the hybrid scaffolds were reinforced by the enrichment of PVA with collagen [47], cartilage ECM components (i.e., hyaluronic acid, chondroitin sulfate) photocrosslinked with PEGDA [17], hydroxyapatite \pm PAA [50-56,66,67], chitosan/GO [70], alginate/PEGDA [72], nanocellulose [60,61], AA [65], and bone/BG [73]. This suggests that the addition of natural materials not only to PVA but also to other synthetic polymers which are normally intended for cartilage TE (i.e., PLGA, polycaprolactone, poly(L-lactic) acid, polyurethane) may represent a valid conceptualization strategy to obtain composite scaffolds that increasingly resemble the mechanical features of native AC.

On the other hand, some authors reported that PVA hydrogel is the main component responsible for the compressive/tensile strength of the composites, and the natural additive confers the hydrogel with enhanced bioactive and lubrication properties $[24,25,44,46,58,59,64]$.

An important role in mechanical reinforcement was reported to be played by the scaffold fabrication technique, with the most effective outcomes obtained through the realization of nanofibers by electrospinning [44] and the control of the crosslinking process by increasing the number of freeze-thawing cycles $[50-56,66]$ or combining physical and chemical methods [68]. This proves that, besides the material, the topographic structure of the scaffold is also of great relevance. In this regard, little attention has been paid to the design and fabrication of PVA-based composites, which closely mimic the complex multizonal architecture of AC to promote spatially dependent tissue growth and cell differentiation. Among the reviewed studies, only one work described the realization of bi-layered composites which tried to replicate the superficial and transitional zones of AC tissue by electrospinning aligned and random PVA/collagen nanofibers onto a freeze-dried collagen sponge [46]. Other authors reported the realization of bi-layered scaffolds, where the combination between the synthetic layer and the natural counterpart was mainly aimed at matching the mechanical strength of the first component with the bioactive/cytocompatible/osteoconductive properties of the second [24,25,45,57,67]. Thus, more efforts should be made to develop scaffolding techniques which may allow re-creating the multilayered structure of AC for the realization of tissue substitutes endowed with higher chondrogenic potential.

Besides scaffold behavior under compressive/tensile forces, the characterization of tribological properties (i.e., friction, lubrication, and wear), as well as the response to creep, tear, adhesion, and shear tests are of paramount importance when considering the fabrication of AC replacements. To our best knowledge, only a few studies in the literature have investigated these mechanical features for PVA-based hybrid scaffolds designed for cartilage TE; this is an aspect that will be worth exploring in the near future. Based on the current evidence, hydroxyapatite, also with added PAA or GO [52,54-56,66,69], and acrylamide [34] are demonstrated to ensure a low friction coefficient when dispersed into the PVA matrix, with the final composite exhibiting a friction response similar to that of AC. Furthermore, matching PVA hydrogel with hydroxyapatite/PAA and acrylamide also produced an adequate response of the hybrid construct to creep and tear deformation $[34,66]$.

A final consideration regards the potential clinical translation of the described PVAbased composites as cartilage TE. From this perspective, biocompatibility assessment of the composite is a key aspect to demonstrating both its biosafety and regenerative potential. Despite some in vitro cell culture studies being reported for these scaffolds, this review of the literature highlighted that their preclinical investigation still presents large gaps to be filled. The clinical translation of new biomaterials is a quite complex process that requires overcoming a variety of preclinical, clinical, and regulatory barriers. The preclinical issues often involve the lack of accurate animal studies which allow prediction of the patient response to biomaterial grafting [90]. Improving the understanding of PVA- 
based composite behavior in the preclinical setting is mandatory to taking the first step toward progress in knowledge that will support the development of trials and regulatory pathways for the clinical translation of these AC replacements.

Author Contributions: Conceptualization, S.B. and A.P.; methodology, S.B., M.C. and E.S.; writingoriginal draft preparation, S.B.; writing-review and editing, S.B., S.T., A.P. and V.M.; supervision, A.P. and R.D.C. All authors have read and agreed to the published version of the manuscript.

Funding: This research received no external funding.

Institutional Review Board Statement: Not applicable.

Informed Consent Statement: Not applicable.

Data Availability Statement: No new data were created or analyzed in this study. Data sharing is not applicable to this article.

Conflicts of Interest: The authors declare no conflict of interest.

\section{References}

1. Temenoff, J.S.; Mikos, A.G. Review: Tissue engineering for regeneration of articular cartilage. Biomaterials 2000, 21, 431-440. [CrossRef]

2. Sophia Fox, A.J.; Bedi, A.; Rodeo, S.A. The basic science of articular cartilage: Structure, composition, and function. Sports Health 2009, 1, 461-468. [CrossRef]

3. Camarero-Espinosa, S.; Rothen-Rutishauser, B.; Foster, E.J.; Weder, C. Articular cartilage: From formation to tissue engineering. Biomater. Sci. 2016, 4, 734-767. [CrossRef]

4. Glyn-Jones, S.; Palmer, A.J.; Agricola, R.; Price, A.J.; Vincent, T.L.; Weinans, H.; Carr, A.J. Osteoarthritis. Lancet 2015, 386, 376-387. [CrossRef]

5. Roseti, L.; Desando, G.; Cavallo, C.; Petretta, M.; Grigolo, B. Articular Cartilage Regeneration in Osteoarthritis. Cells 2019, 8, 1305. [CrossRef] [PubMed]

6. Li, M.H.; Xiao, R.; Li, J.B.; Zhu, Q. Regenerative approaches for cartilage repair in the treatment of osteoarthritis. Osteoarthr. Cartil. 2017, 25, 1577-1587. [CrossRef] [PubMed]

7. Cai, W.; Li, H.; Zhang, Y.; Han, G. Identification of key biomarkers and immune infiltration in the synovial tissue of osteoarthritis by bioinformatics analysis. Peer] 2020, 8, e8390. [CrossRef] [PubMed]

8. Bernhard, J.C.; Vunjak-Novakovic, G. Should we use cells, biomaterials, or tissue engineering for cartilage regeneration? Stem Cell Res. Ther. 2016, 7, 56. [CrossRef] [PubMed]

9. Kumagai, K.; Akamatsu, Y.; Kobayashi, H.; Kusayama, Y.; Saito, T. Mosaic Osteochondral Autograft Transplantation Versus Bone Marrow Stimulation Technique as a Concomitant Procedure with Opening-Wedge High Tibial Osteotomy for Spontaneous Osteonecrosis of the Medial Femoral Condyle. Arthroscopy 2018, 34, 233-240. [CrossRef]

10. Kraeutler, M.J.; Aliberti, G.M.; Scillia, A.J.; McCarty, E.C.; Mulcahey, M.K. Microfracture Versus Drilling of Articular Cartilage Defects: A Systematic Review of the Basic Science Evidence. Orthop. J. Sports Med. 2020, 8, 2325967120945313. [CrossRef]

11. Bhardwaj, N.; Devi, D.; Mandal, B.B. Tissue-engineered cartilage: The crossroads of biomaterials, cells and stimulating factors. Macromol. Biosci. 2015, 15, 153-182. [CrossRef] [PubMed]

12. Lee, S.; Lee, K.; Kim, S.; Jung, Y. Enhanced cartilaginous tissue formation with a cell aggregate-fibrin-polymer scaffold complex. Polymers 2017, 9, 348. [CrossRef] [PubMed]

13. Makris, E.A.; Gomoll, A.H.; Malizos, K.N.; Hu, J.C.; Athanasiou, K.A. Repair and tissue engineering techniques for articular cartilage. Nat. Rev. Rheumatol. 2015, 11, 21-34. [CrossRef] [PubMed]

14. Hwang, N.S.; Varghese, S.; Lee, H.J.; Zhang, Z.; Ye, Z.; Bae, J.; Cheng, L.; Elisseeff, J. In vivo commitment and functional tissue regeneration using human embryonic stem cell-derived mesenchymal cells. Proc. Natl. Acad. Sci. USA 2008, 105, 20641-20646. [CrossRef] [PubMed]

15. Wang, D.A.; Varghese, S.; Sharma, B.; Strehin, I.; Fermanian, S.; Gorham, J.; Fairbrother, D.H.; Cascio, B.; Elisseeff, J.H. Multifunctional chondroitin sulphate for cartilage tissue-biomaterial integration. Nat. Mater. 2007, 6, 385-392. [CrossRef] [PubMed]

16. Lee, K.Y.; Mooney, D.J. Hydrogels for tissue engineering. Chem. Rev. 2001, 101, 1869-1880. [CrossRef] [PubMed]

17. Kim, H.D.; Lee, Y.; Kim, Y.; Hwang, Y.; Hwang, N.S. Biomimetically Reinforced Polyvinyl Alcohol-Based Hybrid Scaffolds for Cartilage Tissue Engineering. Polymers 2017, 9, 655. [CrossRef] [PubMed]

18. Wu, J.; Chen, Q.; Deng, C.; Xu, B.; Zhang, Z.; Yang, Y.; Lu, T. Exquisite design of injectable Hydrogels in Cartilage Repair. Theranostics 2020, 10, 9843-9864. [CrossRef]

19. Gaut, C.; Sugaya, K. Critical review on the physical and mechanical factors involved in tissue engineering of cartilage. Regen. Med. 2015, 10, 665-679. [CrossRef]

20. Drury, J.L.; Mooney, D.J. Hydrogels for tissue engineering: Scaffold design variables and applications. Biomaterials 2003, 24, 4337-4351. [CrossRef] 
21. Mandal, A.; Clegg, J.R.; Anselmo, A.C.; Mitragotri, S. Hydrogels in the clinic. Bioeng. Transl. Med. 2020, 5, e10158. [CrossRef] [PubMed]

22. Teodorescu, M.; Bercea, M.; Morariu, S. Biomaterials of PVA and PVP in medical and pharmaceutical applications: Perspectives and challenges. Biotechnol. Adv. 2019, 37, 109-131. [CrossRef] [PubMed]

23. Sánchez-Téllez, D.A.; Téllez-Jurado, L.; Rodríguez-Lorenzo, L.M. Hydrogels for Cartilage Regeneration, from Polysaccharides to Hybrids. Polymers 2017, 9, 671. [CrossRef]

24. Stocco, E.; Barbon, S.; Dalzoppo, D.; Lora, S.; Sartore, L.; Folin, M.; Parnigotto, P.P.; Grandi, C. Tailored PVA/ECM scaffolds for cartilage regeneration. BioMed Res. Int. 2014, 2014, 762189. [CrossRef] [PubMed]

25. Stocco, E.; Barbon, S.; Radossi, P.; Rajendran, S.; Dalzoppo, D.; Bortolami, M.; Bagno, A.; Grandi, F.; Gamba, P.G.; Parnigotto, P.P.; et al. Autologous chondrocytes as a novel source for neo-chondrogenesis in haemophiliacs. Cell Tissue Res. 2016, 366, 51-61. [CrossRef] [PubMed]

26. Teodorescu, M.; Bercea, M.; Morariu, S. Biomaterials of Poly(vinyl alcohol) and Natural Polymers. Polym. Rev. 2018, 58, 247-287. [CrossRef]

27. Moher, D.; Liberati, A.; Tetzlaff, J.; Altman, D.G.; PRISMA Group. Preferred reporting items for systematic reviews and meta-analyses: The PRISMA statement. Int. J. Surg. 2010, 8, 336-341. [CrossRef]

28. Freed, L.E.; Engelmayr, G.C., Jr.; Borenstein, J.T.; Moutos, F.T.; Guilak, F. Advanced material strategies for tissue engineering scaffolds. Adv. Mater. 2009, 21, 3410-3418. [CrossRef]

29. Becerra, J.; Andrades, J.A.; Guerado, E.; Zamora-Navas, P.; López-Puertas, J.M.; Reddi, A.H. Articular cartilage: Structure and regeneration. Tissue Eng. Part B Rev. 2010, 16, 617-627. [CrossRef]

30. Klein, T.J.; Malda, J.; Sah, R.L.; Hutmacher, D.W. Tissue engineering of articular cartilage with biomimetic zones. Tissue Eng. Part B Rev. 2009, 15, 143-157. [CrossRef]

31. Moutos, F.T.; Freed, L.E.; Guilak, F. A biomimetic three-dimensional woven composite scaffold for functional tissue engineering of cartilage. Nat. Mater. 2007, 6, 162-167. [CrossRef] [PubMed]

32. Antons, J.; Marascio, M.G.M.; Nohava, J.; Martin, R.; Applegate, L.A.; Bourban, P.E.; Pioletti, D.P. Zone-dependent mechanical properties of human articular cartilage obtained by indentation measurements. J. Mater. Sci. Mater. Med. 2018, $29,57$. [CrossRef] [PubMed]

33. Li, L.P.; Herzog, W.; Korhonen, R.K.; Jurvelin, J.S. The role of viscoelasticity of collagen fibers in articular cartilage: Axial tension versus compression. Med. Eng. Phys. 2005, 27, 51-57. [CrossRef]

34. Bodugoz-Senturk, H.; Macias, C.E.; Kung, J.H.; Muratoglu, O.K. Poly(vinyl alcohol)-acrylamide hydrogels as load-bearing cartilage substitute. Biomaterials 2009, 30, 589-596. [CrossRef]

35. Qazi, T.H.; Mooney, D.J.; Pumberger, M.; Geissler, S.; Duda, G.N. Biomaterials based strategies for skeletal muscle tissue engineering: Existing technologies and future trends. Biomaterials 2015, 53, 502-521. [CrossRef] [PubMed]

36. Milner, P.E.; Parkes, M.; Puetzer, J.L.; Chapman, R.; Stevens, M.M.; Cann, P.; Jeffers, J.R.T. A low friction, biphasic and boundary lubricating hydrogel for cartilage replacement. Acta Biomater. 2018, 65, 102-111. [CrossRef]

37. Baker, M.I.; Walsh, S.P.; Schwartz, Z.; Boyan, B.D. A review of polyvinyl alcohol and its uses in cartilage and orthopedic applications. J. Biomed. Mater. Res. B Appl. Biomater. 2012, 100, 1451-1457. [CrossRef]

38. Slaughter, B.V.; Khurshid, S.S.; Fisher, O.Z.; Khademhosseini, A.; Peppas, N.A. Hydrogels in regenerative medicine. Adv. Mater. 2009, 21, 3307-3329. [CrossRef]

39. Weller, W.J. Emerging Technologies in Upper Extremity Surgery: Polyvinyl Alcohol Hydrogel Implant for Thumb Carpometacarpal Arthroplasty and Processed Nerve Allograft and Nerve Conduit for Digital Nerve Repairs. Orthop. Clin. N. Am. 2019, 50, 87-93. [CrossRef]

40. Hendriks, J.; Riesle, J.; van Blitterswijk, C.A. Co-culture in cartilage tissue engineering. J. Tissue Eng. Regen. Med. 2007, 1, 170-178. [CrossRef]

41. Stocco, E.; Barbon, S.; Grandi, F.; Gamba, P.G.; Borgio, L.; Del Gaudio, C.; Dalzoppo, D.; Lora, S.; Rajendran, S.; Porzionato, A.; et al. Partially oxidized polyvinyl alcohol as a promising material for tissue engineering. J. Tissue Eng. Regen. Med. 2017, 11, 2060-2070. [CrossRef] [PubMed]

42. Barbon, S.; Stocco, E.; Dalzoppo, D.; Todros, S.; Canale, A.; Boscolo-Berto, R.; Pavan, P.; Macchi, V.; Grandi, C.; De Caro, R.; et al. Halogen-Mediated Partial Oxidation of Polyvinyl Alcohol for Tissue Engineering Purposes. Int. J. Mol. Sci. 2020, 21, 801. [CrossRef]

43. Alhosseini, S.N.; Moztarzadeh, F.; Kargozar, S.; Dodel, M.; Tahriri, M. Development of Polyvinyl Alcohol Fibrous Biodegradable Scaffolds for Nerve Tissue Engineering Applications: In Vitro Study. Int. J. Polym. Mater. Polym. Biomater. 2015, 64, 474-480. [CrossRef]

44. Filová, E.; Rampichová, M.; Litvinec, A.; Držík, M.; Míčková, A.; Buzgo, M.; Košt'áková, E.; Martinová, L.; Usvald, D.; Prosecká, E.; et al. A cell-free nanofiber composite scaffold regenerated osteochondral defects in miniature pigs. Int. J. Pharm. 2013, 447, 139-149. [CrossRef]

45. Oh, S.H.; An, D.B.; Kim, T.H.; Lee, J.H. Wide-range stiffness gradient PVA/HA hydrogel to investigate stem cell differentiation behavior. Acta Biomater. 2016, 35, 23-31. [CrossRef] [PubMed]

46. Lin, H.Y.; Tsai, W.C.; Chang, S.H. Collagen-PVA aligned nanofiber on collagen sponge as bi-layered scaffold for surface cartilage repair. J. Biomater. Sci. Polym. Ed. 2017, 28, 664-678. [CrossRef] [PubMed] 
47. Lan, W.; Xu, M.; Zhang, X.; Zhao, L.; Huang, D.; Wei, X.; Chen, W. Biomimetic polyvinyl alcohol/type II collagen hydrogels for cartilage tissue engineering. J. Biomater. Sci. Polym. Ed. 2020, 31, 1179-1198. [CrossRef]

48. Chocholata, P.; Kulda, V.; Dvorakova, J.; Kolaja Dobra, J.; Babuska, V. Biological Evaluation of Polyvinyl Alcohol Hydrogels Enriched by Hyaluronic Acid and Hydroxyapatite. Int. J. Mol. Sci. 2020, 21, 5719. [CrossRef]

49. Nayar, S.; Pramanick, A.K.; Sharma, B.K.; Das, G.; Ravi Kumar, B.; Sinha, A. Biomimetically synthesized polymer-hydroxyapatite sheet like nano-composite. J. Mater. Sci. Mater. Med. 2008, 19, 301-304. [CrossRef]

50. Pan, Y.; Xiong, D.; Gao, F. Viscoelastic behavior of nano-hydroxyapatite reinforced poly(vinyl alcohol) gel biocomposites as an articular cartilage. J. Mater. Sci. Mater. Med. 2008, 19, 1963-1969. [CrossRef]

51. Pan, Y.; Xiong, D. Study on compressive mechanical properties of nanohydroxyapatite reinforced poly(vinyl alcohol) gel composites as biomaterial. J. Mater. Sci. Mater. Med. 2009, 20, 1291-1297. [CrossRef] [PubMed]

52. Maiolo, A.S.; Amado, M.N.; Gonzalez, J.S.; Alvarez, V.A. Development and characterization of Poly (vinyl alcohol) based hydrogels for potential use as an articular cartilage replacement. Mater. Sci. Eng. C Mater. Biol. Appl. 2012, 32, 1490-1495. [CrossRef] [PubMed]

53. Yusong, P.; Qianqian, S.; Chengling, P.; Jing, W. Prediction of mechanical properties of multilayer gradient hydroxyapatite reinforced poly(vinyl alcohol) gel biomaterial. J. Biomed. Mater. Res. B Appl. Biomater. 2013, 101, 729-735. [CrossRef] [PubMed]

54. Gonzalez, J.S.; Alvarez, V.A. Mechanical properties of polyvinylalcohol/hydroxyapatite cryogel as potential artificial cartilage. J. Mech. Behav. Biomed. Mater. 2014, 34, 47-56. [CrossRef] [PubMed]

55. Chen, K.; Zhang, D.; Yang, X.; Cui, X.; Zhang, X.; Wang, Q. Research on torsional friction behavior and fluid load support of PVA/HA composite hydrogel. J. Mech. Behav. Biomed. Mater. 2016, 62, 182-194. [CrossRef]

56. Chen, K.; Yang, X.; Zhang, D.; Xu, L.; Zhang, X.; Wang, Q. Biotribology behavior and fluid load support of PVA/HA composite hydrogel as artificial cartilage. Wear 2017, 376-377, 329-336. [CrossRef]

57. Su, C.; Su, Y.; Li, Z.; Haq, M.A.; Zhou, Y.; Wang, D. In situ synthesis of bilayered gradient poly(vinyl alcohol)/hydroxyapatite composite hydrogel by directional freezing-thawing and electrophoresis method. Mater. Sci. Eng. C Mater. Biol. Appl. 2017, 77, 76-83. [CrossRef]

58. Peng, L.; Zhou, Y.; Lu, W.; Zhu, W.; Li, Y.; Chen, K.; Zhang, G.; Xu, J.; Deng, Z.; Wang, D. Characterization of a novel polyvinyl alcohol/chitosan porous hydrogel combined with bone marrow mesenchymal stem cells and its application in articular cartilage repair. BMC Musculoskelet. Disord. 2019, 20, 257. [CrossRef]

59. Scholten, P.M.; Ng, K.W.; Joh, K.; Serino, L.P.; Warren, R.F.; Torzilli, P.A.; Maher, S.A. A semi-degradable composite scaffold for articular cartilage defects. J. Biomed. Mater. Res. A 2011, 97, 8-15. [CrossRef]

60. Millon, L.E.; Oates, C.J.; Wan, W. Compression properties of polyvinyl alcohol-bacterial cellulose nanocomposite. J. Biomed. Mater. Res. B Appl. Biomater. 2009, 90, 922-929. [CrossRef]

61. Li, W.; Wu, Q.; Zhao, X.; Huang, Z.; Cao, J.; Li, J.; Liu, S. Enhanced thermal and mechanical properties of PVA composites formed with filamentous nanocellulose fibrils. Carbohydr. Polym. 2014, 113, 403-410. [CrossRef] [PubMed]

62. Islam, M.M.; Shahruzzaman, M.; Biswas, S.; Nurus Sakib, M.; Rashid, T.U. Chitosan based bioactive materials in tissue engineering applications-A review. Bioact. Mater. 2020, 5, 164-183. [CrossRef] [PubMed]

63. Gorgieva, S.; Trček, J. Bacterial Cellulose: Production, Modification and Perspectives in Biomedical Applications. Nanomaterials 2019, 9, 1352. [CrossRef]

64. Dadgar, N.; Ghiaseddin, A.; Irani, S.; Rabbani, S.; Tafti, S.H.A.; Soufizomorrod, M.; Soleimani, M. Cartilage tissue engineering using injectable functionalized Demineralized Bone Matrix scaffold with glucosamine in PVA carrier; cultured in microbioreactor prior to study in rabbit model. Mater. Sci. Eng. C Mater. Biol. Appl. 2021, 120, 111677. [CrossRef]

65. Mohanapriya, S.; Raj, V. Tuning biological properties of poly (vinyl alcohol) with amino acids and studying its influence on osteoblastic cell adhesion. Mater. Sci. Eng. C Mater. Biol. Appl. 2018, 86, 70-82. [CrossRef]

66. Chen, K.; Liu, J.; Yang, X.; Zhang, D. Preparation, optimization and property of PVA-HA/PAA composite hydrogel. Mater. Sci. Eng. C Mater. Biol. Appl. 2017, 78, 520-529. [CrossRef] [PubMed]

67. Su, W.; Hu, Y.; Zeng, M.; Li, M.; Lin, S.; Zhou, Y.; Xie, J. Design and evaluation of nano-hydroxyapatite/poly(vinyl alcohol) hydrogels coated with poly(lactic-co-glycolic acid)/nano-hydroxyapatite/poly(vinyl alcohol) scaffolds for cartilage repair. J. Orthop. Surg. Res. 2019, 14, 446. [CrossRef] [PubMed]

68. Gan, S.; Lin, W.; Zou, Y.; Xu, B.; Zhang, X.; Zhao, J.; Rong, J. Nano-hydroxyapatite enhanced double network hydrogels with excellent mechanical properties for potential application in cartilage repair. Carbohydr. Polym. 2020, 229, 115523. [CrossRef]

69. Meng, Y.; Cao, J.; Chen, Y.; Yu, Y.; Ye, L. 3D printing of a poly(vinyl alcohol)-based nano-composite hydrogel as an artificial cartilage replacement and the improvement mechanism of printing accuracy. J. Mater. Chem. B 2020, 8, 677-690. [CrossRef] [PubMed]

70. Cao, L.; Zhang, F.; Wang, Q.; Wu, X. Fabrication of chitosan/graphene oxide polymer nanofiber and its biocompatibility for cartilage tissue engineering. Mater. Sci. Eng. C Mater. Biol. Appl. 2017, 79, 697-701. [CrossRef]

71. Chen, Q.; Cabanas-Polo, S.; Goudouri, O.M.; Boccaccini, A.R. Electrophoretic co-deposition of polyvinyl alcohol (PVA) reinforced alginate-Bioglass ${ }^{\circledR}$ composite coating on stainless steel: Mechanical properties and in-vitro bioactivity assessment. Mater. Sci. Eng. C Mater. Biol. Appl. 2014, 40, 55-64. [CrossRef]

72. Yu, F.; Han, X.; Zhang, K.; Dai, B.; Shen, S.; Gao, X.; Teng, H.; Wang, X.; Li, L.; Ju, H.; et al. Evaluation of a polyvinyl alcohol-alginate based hydrogel for precise 3D bioprinting. J. Biomed. Mater. Res. A 2018, 106, 2944-2954. [CrossRef] [PubMed] 
73. Ma, Y.; Zheng, Y.; Huang, X.; Xi, T.; Lin, X.; Han, D.; Song, W. Mineralization behavior and interface properties of BG-PVA/bone composite implants in simulated body fluid. Biomed. Mater. 2010, 5, 25003. [CrossRef]

74. Manavi-Tehrani, I.; Rabiee, M.; Parviz, M.; Tahriri, M.R.; Fahimi, Z. Preparation, Characterization and Controlled Release Investigation of Biocompatible pH-Sensitive PVA/PAA Hydrogels. Macromol. Symp. 2010, 296, 457-465. [CrossRef]

75. Guo, W.; Zheng, X.; Zhang, W.; Chen, M.; Wang, Z.; Hao, C.; Huang, J.; Yuan, Z.; Zhang, Y.; Wang, M.; et al. Mesenchymal Stem Cells in Oriented PLGA/ACECM Composite Scaffolds Enhance Structure-Specific Regeneration of Hyaline Cartilage in a Rabbit Model. Stem Cells Int. 2018, 2018, 6542198. [CrossRef]

76. Ren, Y.; Lou, R.; Liu, X.; Gao, M.; Zheng, H.; Yang, T.; Xie, H.; Yu, W.; Ma, X. A self-healing hydrogel formation strategy via exploiting endothermic interactions between polyelectrolytes. Chem. Commun. 2016, 52, 6273-6276. [CrossRef]

77. Gupta, S.; Goswami, S.; Sinha, A. A combined effect of freeze-Thaw cycles and polymer concentration on the structure and mechanical properties of transparent PVA gels. Biomed. Mater. 2012, 7, 015006. [CrossRef]

78. Millon, L.E.; Wan, W.K. The polyvinyl alcohol-bacterial cellulose system as a new nanocomposite for biomedical applications. J. Biomed. Mater. Res. B Appl. Biomater. 2006, 79, 245-253. [CrossRef] [PubMed]

79. Goodman, S.B.; Yao, Z.; Keeney, M.; Yang, F. The future of biologic coatings for orthopaedic implants. Biomaterials 2013, 34, 3174-3183. [CrossRef] [PubMed]

80. Park, J.C.; Ito, T.; Kim, K.O.; Kim, K.W.; Kim, B.S.; Khil, M.S.; Kim, H.Y.; Kim, I.S. Electrospun poly(vinyl alcohol) nanofibers: Effects of degree of hydrolysis and enhanced water stability. Polym. J. 2010, 42, 273-276. [CrossRef]

81. Koh, Y.G.; Lee, J.A.; Kim, Y.S.; Lee, H.Y.; Kim, H.J.; Kang, K.T. Optimal mechanical properties of a scaffold for cartilage regeneration using finite element analysis. J. Tissue Eng. 2019, 10, 2041731419832133. [CrossRef]

82. Ghasemi-Mobarakeh, L.; Prabhakaran, M.P.; Tian, L.; Shamirzaei-Jeshvaghani, E.; Dehghani, L.; Ramakrishna, S. Structural properties of scaffolds: Crucial parameters towards stem cells differentiation. World J. Stem Cells 2015, 7, 728-744. [CrossRef] [PubMed]

83. Donnelly, H.; Salmeron-Sanchez, M.; Dalby, M.J. Designing stem cell niches for differentiation and self-renewal. J. R. Soc. Interface 2018, 15, 20180388. [CrossRef]

84. Zhang, L.; Hu, J.; Athanasiou, K.A. The role of tissue engineering in articular cartilage repair and regeneration. Crit. Rev. Biomed. Eng. 2009, 37, 1-57. [CrossRef] [PubMed]

85. Huang, A.H.; Yeger-McKeever, M.; Stein, A.; Mauck, R.L. Tensile properties of engineered cartilage formed from chondrocyteand MSC-laden hydrogels. Osteoarthr. Cartil. 2008, 16, 1074-1082. [CrossRef] [PubMed]

86. Blum, M.M.; Ovaert, T.C. Experimental and numerical tribological studies of a boundary lubricant functionalized poro-viscoelastic PVA hydrogel in normal contact and sliding. J. Mech. Behav. Biomed. Mater. 2012, 14, 248-258. [CrossRef]

87. Michael, F.; Wolf, M.F.; Coleman, K.P.; Rankin, E.A.; Lewerenz, G.M. In Vitro Assessment of Cell and Tissue Compatibility. In Biomaterials Science, 4th ed.; Wagner, W.R., Sakiyama-Elbert, S.E., Zhang, G., Yaszemski, M.J., Eds.; Academic Press: Cambridge, MA, USA, 2020; pp. 851-868. [CrossRef]

88. Fini, M.; Giardino, R. In vitro and in vivo tests for the biological evaluation of candidate orthopedic materials: Benefits and limits. J. Appl. Biomater. Biomech. 2003, 1, 155-163. [PubMed]

89. Stoppel, W.L.; Ghezzi, C.E.; McNamara, S.L.; Black, L.D., 3rd; Kaplan, D.L. Clinical applications of naturally derived biopolymerbased scaffolds for regenerative medicine. Ann. Biomed. Eng. 2015, 43, 657-680. [CrossRef]

90. Stace, E.T.; Dakin, S.G.; Mouthuy, P.A.; Carr, A.J. Translating Regenerative Biomaterials into Clinical Practice. J. Cell Physiol. 2016, 231, 36-49. [CrossRef] 